\title{
PERBANDINGAN GAYA BAHASA \\ CERPEN ANGKATAN 66 DENGAN ANGKATAN 2000
}

\author{
Saroni \\ Prodi Pendidikan Bahasa dan Sastra Indonesia \\ Universitas Wiralodra \\ e-mail: saroni@unwir.ac.id
}

\begin{abstract}
ABSTRAK
Sejarah perkembangan sastra nasional terletak pada adanya kesinambungan antara satu periode dengan periode lainnya, baik ditinjau dari segi formal maupun dari segi perkembangan masyarakatperbandingan karya sastra dapat mengembangkan dan memperdalam pemahaman dalam mengapresiasi karya sastra. Salah satunya adalah membandingkan gaya bahasa cerpen Angkatan 66 dengan Angkatan 2000. Akan tetapi kurangnya pengetahuan siswa mengenai gaya bahasa dalam karya sastra khususnya cerpen. Pembelajaran sastra yang digunakan kurang bervariatif, siswa dan guru belum banyak mengenal angkatan dalam sejarah sastra khususnya 66 dan 2000. Rumusan masalah dalam penelitian ini; 1) bagaimanakah gaya bahasa cerpen Angkatan 66?; 2) bagaimana gaya bahasa cerpen Angkatan 2000?; 3) adakah perbedaan gaya bahasa cerpen Angkatan 66 dan Angkatan 2000? Adapun metode yang digunakan adalah metode deskriptif kualitatif, suatu metode yang peneliti sebagai instrumen kunci, pengambilan sampel, sumber data dilakukan secara sengaja dan, teknik pengumpulan dengan gabungan, analisis data bersifat induktif/kualitatif.

Maka dapat diketahui bahwa; 1) Angkatan 66 lebih banyak menggunakan gaya bahasa pada cerpennya dibandimgkan dengan Angkatan 2000; 2) persamaan pada penggunaan gaya bahasa yang sering muncul, yaitu sama-sama sering menggunakan gaya bahasa hiperbola atau menyatakan suatu pernyataan berlebihan dari kenyataannya dengan maksud memberikan kesan mendalam atau meminta perhatian; 3) perbedaan yang terjadi pada gaya bahasa cerpen dari kedua angkatan tersebut Angkatan 66 lebih banyak menggunakan gaya bahasa metafora atau majas yang mengungkapkan ungkapan secara langsung berupa perbandingan analogis sedangkan Angkatan 2000 yang lebih banyak menggunakan gaya bahasa pleonasme atau majas yang menggunakan kata-kata secara berlebihan dengan maksud menegaskan arti suatu kata.
\end{abstract}

\section{Kata Kunci: perbandingan, gaya bahasa, cerpen, Angkatan 66, Angkatan 2000.}

\section{PENDAHULUAN}

Sejarah perkembangan sastra
nasional terletak pada adanya kesinambungan antara satu periode dengan periode lainnya, baik ditinjau dari segi formal maupun dari segi perkembangan masyarakat. Sejarah perkembangan tersebut mempelajari ciri-ciri karya sastra pada masa tertentu, para sastrawan, dan peristiwaperistiwa yang terjadi seputar karya sastra.
Perjalanan sastra dari waktu ke waktu dapat dipelajari dan dipahami melalui kebudayaan bangsa. Terbukti pada tahun 1930-an pertumbuhan sastra di Indonesia sudah nampak pada Polemik Kebudaayan Suntingan Achdiat K. Mihardja (1977). Polemik yang berkembang antara tokohtokoh S.Takdir Alisjahbana, Sanusi Pane, Poerbatjaraka, M.Amir, Ki Hadjar Dewantara, Adinegoro dan lain-lain 
memang tidak secara khusus memperdebatkan konsep kesusastraan Indonesia, tetapi telah memperlihatkan kesadaran mereka terhadap sejarah kebudayaan Indonesia.Hingga sekarang sejarah sastra Indonesia telah berlangsung relatif panjang dengan perkembangan yang cukup pesat dan dinamik sehingga dapat ditulis secara panjang lebar.

Berdasarkan urutan waktu, sastra Indonesia terbagi atas beberapa angkatan. Salah satunya adalah angkatan 66 yang dikemukakan oleh H.B. Jassin. Angkatan 66 muncul di tengah-tengah keadaan politik bangsa Indonesia yang sedang kacau. Kekacauan politik itu terjadi karena adanya teror PKI. Akibat kekacauan politik itu, berdampak pada kekacauan dalam bidang kesenian dan kesusastraan. Akibatnya, kelompok Lekra di bawah PKI bersaing dengan kelompok Menikebu yang memegang sendi-sendi kesenian, kedamaian, pembangunan bangsa, dan Pancasila. Ciri-ciri angkatan 66 yaitu tema protes sosial dan politik, bercorak realisme, mementingkan isi, banyak menggunakan gaya retorik, dan slogan, serta memperhatikan nilai estetis. Kemudian angkatan 2000 periode yang lahir dengan semangat revolusiner kemungkinan periode ini merupakan jendela bagi perkembangan kesusastraan di Indonesia, tema sosial politik, romantik masih mewarnai, banyak muncul kaum perempuan, cenderung vulgar, mulai bermunculan fiksi-fiksi Islami,karya populer gampang dicerna, muncul cyber sastra di internet.

Salah satu pengelolaan bahasa dari setiap periode adalah gaya bahasa. Gaya bahasa merupakan cara seseorang mengungkapkan pikiran dan perasaan melalui pikiran yang khas yang memperlihatkan jiwa dan kepribadian pemakaian bahasa. Gaya bahasa memungkinkan seseorang menilai, watak pribadi, dan kemampuan seseorang pengarang. Gaya bahasa dapat menambah intensitas pengarang serta menambah ketajaman penyampaian sikap pengarang.
Perbandingan karya sastra dapat mengembangkan dan memperdalam pemahaman dalam mengapresiasi karya sastra. Salah satunya adalah membandingkan gaya bahasa cerpen Angkatan 66 dengan Angkatan 2000 sebagai contoh Seno Gumira Ajidarma yang mewakili Angkatan 66 dan Titis Basino yang mewakili Angkatan 2000. Pada kedua cerpenis tersebut tampak adanya gaya bahasa yang berbeda. Titis Basino cerpenis cenderung menggunakan gaya bahasa baku dan sedikit sukar dipahami, sedangkan Seno Gumira Ajidarma lebih menonjolkan gaya bahasa yang modern dan lebih mudah dipahami.

Masalah cerpen dan gaya bahasa terdapat dalam kurikulum 2013 pelajaran Bahasa Indonesia di Sekolah Menengah Atas (SMA). Kompetensi dasar mata pelajaran Bahasa Indonesia pada cerpen yaitu siswa mampu menganalisis unsurunsur pembangun cerita pendek dalam kumpulan cerita pendek, siswa mampu mengkonstruksikan sebuah cerita pendek dengan memerhatikan unsur-unsur pembangun cerpen dengan materi pembelajaran unsur instrinsik dan ekstrinsik cerpen, kebahasaan cerpen meliputi majas, peribahasa, dan ungkapan. Lalu ruang lingkup mata pelajaran Bahasa Indonesia untuk kategori peminatan yaitu periode sastra dan sejarah sastra.

Beberapa peneliti yang mengkaji gaya bahasa cerpen diantaranya M. Agus Kuswanto dengan judul "Gaya Bahasa Perbandigan dalam Kumpulan cerpen Seno Gumira Ajidarma serta Implikasinya terhadap Pembelajaran Bahasa dan Sastra Indonesia. Penelitian ini bertujuan (1) mengetahui penggunaan gaya bahasa perbandingan dalam kumpulan cerpen Seno Gumira Ajidarma, dan (2) mengetahui implikasi penggunaan majas perbandingan tersebut dalam pembelajaran Bahasa dan Sastra di sekolah. Subjek penelitian ini adalah kumpulan cerpen Saksi Mata karya Seno 
Gumira Ajidarma, sedangkan yang menjadi objek dalam penelitian ini adalah implikasi penggunaan majas perbandingan. Teknik yang digunakan n Saksi Mata dan metode penelitian kualitatif yang digunakan peneliti yaitu analisis isi.

Penelitian lain yang juga membahas gaya bahasa adalah Ihda Aulianisa yang berjudul "Gaya Bahasa Perbandingan dalam Kumpulan Cerpen Murjangkung Cinta dan Hantu-Hantu karya AS Laksana. Penelitian ini bertujuan (1) mengetahui penggunaan gaya bahasa perbandingan dalam kumpulan cerpen Murjangkung Cinta yang Dungu dan Hantu-Hantu Karya AS Laksana, dan (2) mengetahui implikasi gaya bahasa perbandingan di sekolah. Subjek penelitian ini kumpulan cerpen Murjangkung Cinta Dungu dan HantuHantu lalu subjek penelitian ini implikasi terhadap pembelajaran Bahasa dan Sastra di SMA. Teknik yang diguanakan dalam penelitian ini membaca dan memahami kumpulan cerpen secara cermat lalu metode penelitian ini adalah kualitatif deskriptif.

Dua penelitan yang di atas tidak melakukan perbandingan terhadap dua periode angkatan. Sementara itu penelitian ini lebih menekankan kepada membandingkan gaya bahasa dari dua angkatan. Penelitian ini juga dikaitkan dengan penyusunan model gaya bahasa di SMA. Oleh karena itu, penelitian ini berjudul Perbandingan Gaya Bahasa Cerpen Angkatan 66 dengan Angkatan 2000.

Untuk mencapai hasil penelitian yang maksimal dan terarah, maka diperlukan perumusan masalah dalam sebuah penelitian. Adapun perumusan masalah dalam penelitian ini sebagai berikut.

1. Bagaimanakah gaya bahasa cerpen Angkatan 66?

2. Bagaimana gaya bahasa cerpen Angkatan 2000? dalam penelitian ini menggunakan teknik simak, yakni berusaha menyimak penggunaan bahasa dalam kumpulan cerpe

3. Adakah berbedaan gaya bahasa cerpen Angkatan 66 dan Angkatan 2000?

\section{Tinjauan Pustaka \\ Sastra Bandingan}

Menurut Endaswara (2011:112) sastra bandingan adalah penelitian yang tidak hanya berusaha mengkaji persamaan dan perbedaan antarkarya sastra secara tekstual, namun lebih jauh lagi yakni berusaha mengetahui latar belakang kehidupan sosial budaya yang mendasari lahirnya sebuah teks. Damono (2005: 2) menyatakan bahwa sastra bandingan merupakan pendekatan dalam ilmu sastra yang tidak menghasilkan teori tersendiri.

Sastra Bandingan dalam kajian umum serta dalam kaitannya dengan sejarah ataupun yang lainnya adalah bagian dari sastra. Bagaimana menghubungkan sastra yang satu dengan yang lain, dan bagaimana pengaruh keduanya, serta apa yang dapat diambil dari sastra ini dan apa yang diberikannya. Atas dasar inilah kajian dalam sastra bandingan bersifat berpindah dari satu sastra ke sastra yang lain. Sastra banding adalah wilayah keilmuan sastra yang mempelajari keterkaitan antara sastra dan perbandingan sastra dengan bidang lain. Jalin-menjalin karya sastra dimungkinkan karena setiap pengarang menjadi bagian dari penulis lain. Dengan kata lain, istilah sastra banding dan sastra perbandingan dalam konteks ini digunakan bersama-sama. Namun, untuk mempermudah akan digunakan sastra banding, karena lebih akrab dan sering digunakan dalam berbagai forum ilmiah yang paling terkemuka. Ilmu sastra menjadi pijakan sastra banding. Tujuan sastra banding (1) untuk mencari 
pengurut karya sastra satu dengan yang lain, (2) untuk menentukan karya sastra yang benar-benar original dan mana yang bukan dalam lingkup perjalanan sastra, (3) untuk menghilangkan kesan karya sastra nasional tertentu lebih hebat disbanding karya sastra nasional yang lain, (4) mencari keragaman budaya dalam karya sastra, (5) untuk memperkokoh keuniversalan konsepkonsep keindahan karya sastra, (6) menilai mutu karya-karya dari negaranegara dan keindahan karya sastra.

\section{Cerita Pendek}

Cerpen singkatan dari cerita pendek.Akan tetapi, tidak semua cerita yang pendek disebut cerpen, cerpen sendiri biasanya berdasarkan pemikiran dari pengalaman pengarangnya, kemudian pengalaman itu diolah sedemikian rupa sehingga menjadi lebih menarik untuk dibaca. Cerpen (cerita pendek sebagai genre fiksi) adalah rangkaian peristiwa yang terjalin menjadi satu yang di dalamnya terjadi konflik antartokoh atau dalam tokoh itu sendiri pada latar dan alur, peristiwa dalam cerita berwujud hubungan antara, tokoh, tempat, dan waktu yang membentuk satu kesatuan (Kurniawan, 2012:59).

Sifat dari cerpen adalah naratif jadi cerpen bukan argumentasi atau analisis atau deskriptif. Kelebihan cerpen yang khas adalah kemampuannya mengemukakan secara lebih banyak, secara implisit dari sekadar apa yang diceritakan. Sifat fiktif naratif keberadaannya lebih dari memberi kesenangan untuk para pembacanya.Hal itu berbeda dengan teks bergenre faktual.Meskipun demikian, cerita pendek juga tidak lepas dari kehadiran nilai-nilai tertentu di balik kisah yang mungkin mengharukan, meninabobokan, dan mencemaskan.Sebuah cerpen sering mengandung hikmah atau nilai-nilai yang biasa dipetik dalam perilaku tokoh ataupun di antara kejadian-
kajadiannya.Kejadian cerpen tidak perlu berwujud perbuatan, tapi bisa pergulatan batin, dan hanya boleh ada satu kejadian saja.Penceritaan atau narasi dari satu kejadian itu harus dilakukan dengan hemat.Inilah sebabnya dalam cerpen dituntut hanya ada dua atau tiga tokoh saja yang penting dan satu konflik yang menggerakkan cerita, ringkasan semuanyaharus serba ekonomis sehingga hanya satu kesan yang diberikan pada pembaca.

Secara umum dapat disimpulkan bahwa, cerita pendek harus berupa cerita atau narasi (bukan analisis argumentatif) yang fiktif, tidak benar-benar telah terjadi tetapi bisa terjadi, di mana saja dan kapan saja.Ukuran panjang pendeknya suatu cerita memang relatif.Namun, pada umumnya cerita pendek merupakan cerita yang habis dibaca sekitar sepuluh menit atau setengah jam.Jumlah katanya sekitar 500-5.000 kata (Kosasih, 2014:111). Cerpen ialah interpretasi pengarang terhadap kehidupan. Kehidupan yang digambarkan cerpen bukan kehidupan otentik, tapi kehidupan menurut saringan pandangan pengarang.Kejadian dalam cerpen adalah pengalaman subjektif pengarang. Makin besar kepribadian pengarang makin terpercaya apa yang diungkapkan, dan kehidupan yang dipaparkan dalam cerpen adalah kehidupan dalam bentuk intinya, yang penuh arti, yang intens (Sumardjo, 2004:12).

Sebuah cerpen tak lepas dari dua struktur yaitu instrinsik dan ekstrinsik. Struktur instrinsik adalah unsur yang terkandung dalam cerita, unsur instrinsik meliputi, tema, alur, tokoh, gaya bahasa, latar, amanat dan lain sebagainya yang berpengaruh membangun jalannya cerita. Sedangkan unsur ekstrinsik adalah unsur pembangun dari luar yang tidak ditemukan pada contoh meliputi adat istiadat, budaya, pendidikan dari pengarang dan lain sebagainya.Struktur karya fiksi menyaran pada pengertian 
hubungan antar unsur (instrinsik) timbal balik, saling menentukan, saling mempengaruhi, yang secara bersamasama membentuk satu kesatuan yang utuh (Nurgiantoro, 2010:36).

\section{Gaya Bahasa}

Gaya adalah keseluruhan cara yang dilakukan dalam aktivitas kehidupan sehari-hari, baik lisan maupun tulisan. Gaya diangkat dari istilah style berasal dari bahasa latinstilus yang mengandung arti alat untuk menulis, secara definitif stilistika adalah ilmu yang berkaitan dengan gaya dan gaya bahasa. Jadi, pengertian yang paling luas, stilistika, sebagai ilmu tantang gaya, meliputi berbagai cara yang dilakukan manusia (Ratna, 2014:167). Tidak ada kegiatan yang dilakukan tanpa menggunakan gaya tertentu. Dalam karya sastra gaya mengandung pengertian cara seorang pengarang menyampaikan gagasannya dengan menggunakan media bahasayang indah dan harmonis serta mampu menuansakan makna dan suasana yang dapat menyentuh daya intelektual dan emosi pembaca (Aminuddin, 2013:72).

Gaya adalah kemampuan untuk menunjukan ciri khas dalam mengaktualisasikan diri, baik itu melalui lisan maupun tulisan. Istilah gaya lebih dikenal style. Penekanan menititik beratkan pada keahlian untuk menulis indah, maka style berubah menjadi kemampuan dan keahlian untuk menulis dan mempergunakan kata-kata secara indah (Keraf, 2009:112). Maka penulis atau pengarang menggunakan gaya bahasa untuk memperindah tulisannya dan menguatkan maknanya. Gaya adalah cara-cara yang khas bagaimana segala sesuatu diungkapkan dengan cara tertentu, sehingga tujuan yang dimaksudkan dapat dicapai secara maksimal dan bagaimana seseorang pengarang memilih tema, persoalan, meninjau persoalan, dan menceritakannya dalam sebuah cerpen.
Baik gaya maupun gaya bahasa berkaitan dengan aspek keindahan. Perbedaanya, dalam kehidupan seharihari, aktivitas nonseni gaya menduduki posisi sekunder, sedangkan dalam karya sastra dan karya seni pada umumnya keindahan merupakan gejala dominan. Proses penciptaan gaya bahasa jelas disadari oleh penulisnya. Dalam penulisanya, untuk memperoleh aspek keindahan secara maksimal, dan menemukan satu kata atau kelompok kata yang dianggap tepat penulis melakukannya secara berulang-ulang. Peristiwa seperti ini dapat dibuktikan dengan adanya konsep yang penuh dengan coretan, penghapusan, dan pengganti dengan kata-kata yang baru.

Dalam hubungan dengan sastra, hal ini berkaitan dengan cara pengarang dalam mengungkapkan segala sesuatu dalam karya sastra dengan cara tertentu sehingga maksud pengarang tersampaikan kepada pembaca. Dengan kata lain bahwa gaya adalah pribadi pengarang itu sendiri. Gaya bahasa dalam penulisan sastra juga tak lepas dari halhal di atas. Gaya bahasa akan menjadi sastra karena memang ditulis dalam konteks kesastraan, ditambah tujuan mendapatkan efek keindahan yang menonjol dan menjadi kemampuan untuk menulis atau menggunakan kosakata secara indah. Bila dilihat dari fungsi bahasa, penggunaan bahasa termasuk dalam fungsi puitik yaitu menjadikan pesan lebih berbobot.

Pemakaian gaya bahasa yang tepat (sesuai dengan waktu dan penerima yang menjadi sasaran) dapat menarik perhatian penerima. Sebaliknya bila penggunaan tidak tepat, maka penggunaan gaya bahasa akan sia-sia belaka. Pendapat lain mengatakan pemajasan merupakan teknik penggunaan bahasa, penggayabahasaan, yang maknanya tidak menunjuk pada makna harfiah kata-kata mendukungnya, melainkan pada makna yang ditambahkan, makna yang tersirat 
(Nurgiantoro, 2007:296). Gaya bahasa adalah cara yang digunakan penulis untuk membangkitkan dan menciptakan imaji dengan menggunakan perbandingan, kiasan, dan perlambangan. Pada hakikatnya gaya merupakan teknik pemilihan ungkapan kebahasaan yang dapat mewakili sesuatu yang digunakan, teknik ini juga merupakan suatu bentuk pilihan-pilihan dan pilihan ini dapat dilihat dalam bentuk ungkapan bahasa seperti yang dipergunakan dalam sebuah karya. Berdasarkan beberapa pendapat, dapat dikatakan secara garis besar bahwa gaya bahasa merupakan penyimpangan makna dari kata-kata yang tertulis yang sengaja dilakukan oleh pengarang untuk menimbulkan efek tertentu atau menimbulkan konotasi tertentu.

Karya sastra dan gaya bahasa dibedakan menjadi dua macam, yaitu a) gaya karya sastra populer, dan b) gaya sastra serius. Selain itu gaya dibedakan pula berdasarkan kualitasnya, kualitas itulah yang secara garis besarpada gilirannya juga dibedakan menjadi tiga macam, yaitu: a) gaya bahasa dengan kualitas rendah, b) kualitas menengah, dan c) gaya bahasa dengan kualitas tinggi.

\section{Angkatan 66}

Angkatan 66 adalah suatu kenyataan sejarah bahwa sejak awal pertumbuhannya sastrawan-sastrawan Indonesia menunjukkan perhatian yang serius kepada politik. Pada masa ini sastra sangat dipengaruhi oleh lembaga kebudayaan seperti Lekra dan Manikebu.Pada tahun 1961 Lekra, organ PKI yang memperjuangkan komunisme, dinyatakan sebagai organisasi kebudayaan yang memperjuangkan slogan "politik adalah panglima". Sementara Menifes Kebudayaan merupakan sebuah konsep atau pemikiran di bidang kebudayaan dan merupakan sebuah reaksi terhadap teror budaya yang pada waktu itu dilancarkan oleh orang- orang Lekra. Manifes kebudayaan dituduh anti-Manipol dan kontra Revolusioner sehingga harus dihapuskan dari muka bumi Indonesia. Pelarangan Manifes Kebudayaan diikuti tindakan politis yang makin memojokkan orangorang Manifes Kebudayaan, yaitu pelarangan buku karya pengarangpengarang yang berada di barisan.

Secara politis Angkatan 66 terlahir dari pergolakan politik dalam masyarakat.Kelahirannya adalah suatu peristiwa politik. Tapi di samping ukuran politik, di bidang kesusatraan ia mempunyai ukuran nilai, yaitu nilai kesusatraan, ia anti tirani, menegakkan keadilan dan kebenaran. Dan kesenian senantiasa anti kezaliman, ingin kebajikan.Keadilan dan kebenaran itu dituangkan dalam hasil kesenian, hasil kesusatraan. Apabila seniman Berjaya menuangkan nilai-nilai dalam hasil seninya, maka ia telah mengatasi dataran politik. Ia telah tiba di negri utopia. Seniman yang berbeda-beda dalam kehidupan politik, dalam kehidupan sehari-hari, akan bertemu dalam dunia penciptaan, dalam dunia ide. Hal ini dapat diilustrasikan dengan hasil-hasil karya "pendukung-pendukung Sukarno" yang sama sekali tidak memperlihatkan sesuatu yang bertentangan dengan nilainilai kemanusiaan yang universal: cinta tanah air, bahagia hidup kemasyarakatan, anti kebatilan. Kontroversi yang berdasarkan politik ini lambat laun akan hilang, apa bila Orde Baru telah betulbetul menguasai lapangan dan tidak ada sesuatu kekhatiran lagi akan kembalinnya Gestapu PKI (Jassin, 2013:8).

\section{Angkatan 2000}

Angkatan 2000 adalah kumpulan nama-nama sastrawan dan karyakaryanya pada tahun 2000 di dalamnya seratus lebih penyair, cerpenis, novelis, eseis, dan kritikus sastra dimasukkan Korie Layun Rampan ke dalam buku Angkatan 2000. Munculnya angkatan ini 
ditandai dengan maraknya karya sastra yang bertemakan seputar reformasi. Sastrawan Angkatan Reformasi merefleksikan keadaan sosial dan politik yang terjadi pada akhir tahun 1990-an seiring dengan adanya Orde Baru. Pada Angkatan 2000 karya sastra berperan untuk membentuk pemikiran tentang keindonesiaan setelah mengalami kombinasi dengan pemikiran lain, seperti budaya. Ide, filsafat, dan gebrakangebrakan baru muncul di era ini, beberapa karya keluar dari paten dengan memperbincangkan agama dan mulai bermunculan kubu-kubu sastra populer dan sastra majalah.Pada Angkatan 2000 pula karya yang bersifat absurd mulai tampak. Di tahun 1980-1990-an banyak penulis Indonesia yang berbakat. Salah satu penerbit yang terkenal sampai sekarang adalah Gramedia. Gramedia merupakan penerbit yang memperhatikan sastra dan membuka ruang untuk semua jenis sastra sehingga penulis Indonesia senantiasa memiliki kreativitas dengan belajar dari berbagai paten karya, baik itu karya populer, kedaerahan, maupun karya urban

Sementara setelah masa reformasi, yaitu tahun 2000-an, kondisi sastra tanah air digambarkan sebagai kritik rezim orde baru, wacana urban dan adsurditas kritik pemerintah terus berjalan Sastra masuk melalui majalah selain majalah sastra.Sastra bersanding dengan seni lainnya, banyak terjadi alih wahana pada jaman sekarang. Karya yang dilarang terbit pada masa 70-an diterbitkan di tahun 2000-an, banyak karya yang diterbitkan, karya Hersri Setiawan, Remy Sylado, dan sebagainya.

Adapun ciri dari Angkatan 2000 ialah (1) karya cenderung vulgar (2) mulai bermunculan fiksi-fiksi islami (3) muncul cyber sastra di internet (4) bahasa kerakyatjelataan. Seperti seorang anak, Sastra mengalami masa pertumbuhan. Masa pertumbuhan sastra tidak akan dewasa hingga zaman mengurungnya.
Sastra akan terus menilai zaman melalui pemikiran dan karya sastrawannya. Pada tahun 1970-an, sastra memiliki karakter yang keluar dari paten normatif. Pada tahun 1980-an hingga awal 1990-an, sastra memiliki karakter yang diimbangi dengan arus budaya populer. Pada tahun 2000-an hingga saat ini, sastra kembali memiliki keragaman kahzanah dari yang populer, kritik, reflektif, dan masuk ke ranah erotika dan absurditas.

\section{METODOLOGI PENELITIAN}

Metode yang digunakan dalam penelitian ini adalah metode deskriptif kualitatif. Penelitian deskriptif kualitatif yaitu suatu metode yang peneliti sebagai instrumen kunci, pengambilan sampel, sumber data dilakukan secara sengaja dan, teknik pengumpulan dengan gabungan, analisis data bersifat induktif/kualitatif, dan hasil penelitian kualitatif lebih menekankan makna dari pada generasi (Sugiono, 2009:15). Dengan menggunakan metode deskriptif, seorang peneliti sastra dituntut mengungkapkan fakta-fakta yang tampak atau data dengan cara memberi deskriptif dan harus diambil berdasarkan parameter yang jelas. Sebagai prosedur pemacahan masalah dengan menggambarkan atau melukiskan keadaan subjek dan objek penelitian pada saat sekarang berdasarkan fakta-fakta yang tampak atau sebagaimana adanya. Oleh karena itu, peneliti tidak bermaksud untuk menjawab hipotesis tetapi lebih ditekankan pada pengungkapan pemahaman terhadap masalah penelitian.

\section{HASIL DAN PEMBAHASAN}

Analisis Gaya Bahasa Cerpen Angkatan 66 Cerpen "Mbah Danu" karya Nugroho Notosusanto

\section{1) Sinopsis Cerpen}

Mbah Danu adalah seorang dukun yang sakti dan sangat disegani oleh penduduk, mbah Danu dapat menyembuhkan orang sakit dengan mantramantranya, ia dapat juga mengusir roh-roh jahat seperti setan, jin yang sering merasuki 
orang sakit panas.Dukun ini kemudian dipertemukan dengan orang yang berpendidikan modern yaitu Mr. Salyo, menantu pak Jaksa (pensiun), ia tak kenal ilmu ghoib dan hal-hal yang takhayul. Akhirnya mbah Danu tidak mampu mengobati sakit mbok Rah (pembantu Pak Jaksa). Ketika mbok Rah sakit, dipanggilnya dr. Umar Chattab yang melakukan tugasnya secara ilmiah. Menurut diagnosadr. Umar ChattabMbok Rah mengidap penyakit malaria. Untuk menyembuhkan ia harus makan pil kinine.Ternyata Mbok Rah jiwanya tidak tertolong. Orang cenderung menyalahkan menantu Pak Jaksa yaitu Mr. Salyo, yang mengundang dokter Umar untuk mengobati Mbok Rah itu. Tetapi sebenarnya tidaklah begitu, sebab ketika mayat Mbok Rah sudah dikuburkan penduduk, ternyata di bawah balai-balai Mbok Rah terdapat pil kinine menumpuk.

\section{2) Gaya Bahasa Cerpen "Mbah Danu"}

a) Majas Metafora

(1) Pada cerpen ini terdapat kalimat "Wajahnya keras-keras seperti tengkorak, kulitnya liat seperti belulang" kalimat ini mengungkapkan ungkapan secara langsung berupa perbandingan analogis dari wajah Mbah danu yang keras seperti tengkorak karena pengarang cerpen ingin menjelaskan kepada pembaca sosok Mbah Danu yang sudah tua.

(2) Adapun kalimat lain yang menunjukan ungkapan perbandingan analogis yakni "pipinya selalu menonjol oleh susur tembakau yang ada dalam mulutnya, jalannya tegak seperti seorang maharani yang angkuh" menjelaskan bahwa Mbah Danu berjalan seperti seorang maharani.

(3) Kemudian kutipan "Menurut kabarkabar yang cepatnya tersiar hampir seperti berita radio, Mbah Danu sedang turne" menjelaskan informasi keberadaan Mbah Danu yang sedang berpergian dari satu daerah ke daerah lain.
(4) Kutipan selanjutnya yaitu "Mbah Danu datang membawa koper besi yang sama antiknya dengan yang punya" menjelaskan bahwa ketika Mbah Danu datang ia membawa koper besi yang usia koper tersebut sama tua nya dengan Mbah Danu.

(5) Selamjutnya pada kutipan "napas si sakit seperti ububan pandai besi bunyinya" menggambarkan bahwa nafas Nah yang dikiaskan seperti ububan untuk membuat api menyala ketika membuat alat dari besi yang kala itu ia tersadar dari jeritannya.

b) Majas Asosiasi

(1) Pada kalimat "wajahnya pucat seperti kain mori" ungkapan ini membandingkan dua hal yang pada hakikatnya berbeda, tetapi sengaja dianggap sama bahawa wajah Mbok Rah Pucat seperti kain mori yaitu kain mori benda yang tak bernyawa dikiaskan seolah-olah warna putih kain mori seperti wajah Mbok Rah .

(2) Kutipan berikutnya yang membandingkan dua hal yang hakekatnya berbeda, tetapi tetati sengaja dianggap sama "bantalnya yang kumal seperti tempat duduk Jeep militer yang sudah tua" mengambarkan Nah yang terbaring sakit sedang mengigau hingga keluar cairan dari mulutnya.

(3) Selanjutnya yaitu kutipan "kegelian seperti perawan yang sehat" menggambarkan keadaan $\mathrm{Na} h$ yang sedang di obati dengan cara meremasremas seluruh badan Nah sambil menggelitik hingga Nah merasa geli.

c) Majas Alegori

Pada kalimat "Gerak-geriknya percis bantara durga yang menari di atas mayat manusia. Setelah sudah ia, menelentangkan badan Nah yang keringatnya membuat lantai mengkilat basah dan mukanya kini merah padam" kutipan ini menjelaskan suatu penggambaran melalui kiasan gerak Mbah Danu seperti bantara durga yang menari di atas mayat bahwa mbah danu 
melentangkan badan Nah dengan maksud ingin menyembukan Nah.

d) Majas Simbolik

(1) Pada kutipan cerpen "Nah tengah mengeong-ngeong seperti kucing kasmaran" majas yang melukiskan sesuatu dengan mempergunakan benda, binatang, atau tumbuhan sebagai simbol atau lambang. Menjelaskan situasi Nah tengah meringik kesakitan karena sakit yang dideritanya.

(2) Selanjutnya majas yang melukiskan seuatu dengan mempergunakan binatang terdapat pada kutipan cerpen "mengaum seperti singa sirkus yang marah" menggambarkan keadaan tokoh Nah yang sedang menangis dan menjerit kesakitan ketika Mbah Danu memukulnya dengan sapu lidi.

\section{e) Majas Hiperbola}

Pada kutipan cerpen "dia tembusi badan Nah dengan pandang yang membara" majas yang berupa pernyataan berlebihan dari kenyataannya dengan maksud memberikan kesan mendalam atau meminta perhatian pada situasi tersebut Mbah danu memandangi Nah dengan tajam.

f) Majas Pleonasme

(1) Pada kutipan cerpen “...perintah Mbah Danu dengan sikap Srikandi wayang orang" majas yang menggunakan katakata secara berlebihan yaitu sikap srikandi dengan maksud menegaskan arti suatu gaya Mbah Danu ketika menyuruh seseorang untuk mengambil sapu lidi.

(2) Berikutnya majas yang menggunakan kata-kata yang berlebihan dengan maksud menegaskan arti suatu kata yaitu "Perang dingin kini mencair jadi gugatan-gugatan lisan yang pedas" menggambarkan situasi dimana Nyonya Saljo dan Dr. Umar sedang mempertanya apakah diminum atau tidak obat yang telah diberikan Dr. Umar untuk Mbok Rah.

(3) Selanjutnya yaitu kutipan "pil kinine membukit di lantai" pil yang diberikan kepada Mbok Rah agar diminum ternyata sama sekali tidak dimumnya melainkan dibuang oleh Mbok Rah sendiri sehingga menjadi gundukan obat.

\section{Cerpen "Seribu Kunang-kunang Di Mahanttan" karya Umar Kayam \\ 1) Sinopsis Cerpen}

Cerpen ini menceritakan sepasang manusia yang bernama Jane dan Marno. Mereka menjalin sebuah hubungan Marno sudah mempunyai seorang istri sedangkan jane baru bercerai dengan suaminya mereka sama-sama sedang memandang di luar jendela. Mereka berdebat tentang warna bulan Jane menganggap bulan itu berwarna ungu namun, tidak dengan Marno tidak putus asa, Jane tetap bersikeras untuk meyakinkan Marno. Marno berdiri, ke dapur untuk mengambil air serta es ke dalam gelasnya setelah itu, ia kembali ke sofa di samping Jane. Tiba-tiba Jane teringat dengan Tommy, bekas suaminya dahulu. Ia bertanya kepada Marno bagaimana Alaska kondisi dan hawa di Alaska. Jane juga berkata bahwa Tommy sekarang ada di Alaska. Jane menganggap bahwa Tommy sedang ada di Alaska. Jane tidak ingin Tommy kedinginan karena Alaska sangat dingin. Namun, Marno memberitahu Jane bahwa belum tentu Tommy berada di Alaska sekarang.

Ada yang mengganjil dalam benak Marno ia merasa dekat dengan istrinya pada malam itu lalu dia memutuskan meninggalkan Jane pada malam itu dan bergegas pulang, Jane merasa kesepian dia tak bisa tidur waklaupun sudah meminum obat tidur tanpa daia sadari ternyata sedari tadi dia sudah menangis karna ditinggalkan marno.

\section{2) Gaya Bahasa Cerpen "Seribu Kunang-kunang Di Mahanttan"}

a) Majas Retorik

Pada kalimat "Marno tidak menjawab, karena tiba-tiba saja dia merasa seakanakan istrinya ada di dekat-dekat dia di Manhattan malam itu. Adakah 
penjelasan bagaimana satu bayangan yang terpisah beribu-ribu kilometer bisa muncul begitu saja dalam waktu yang begitu pendek?" ungkapan pertanyaan seperti ini adalah majas yang tidak perlu jawaban karena menjelaskan tentang perasaan seorang suami kepada istrinya ketika suami membagi cinta dengan wanita lain perasaan bersalah yang tibatiba muncul dari benak suami.

b) Majas Simbolik

Pada kalimat "Dan Jane seperti seekor kijang yang mendapatkan kembali kekuatannya sesudah terlalu lama berteduh, melompat-lompat masuk ke dalam kamarnya. Beberapa menit kemudian dengan wajah berseri dia keluar kembali dengan sebuah bungkusan di tangan" ungkapan ini adalah berupa majas simbolik karena melukiskan sesuatu dengan mempergunakan binatang sebagai symbol lambang. Terlihat pada kutipan jane seperti seekor kijang yang mendapatkan kembali kekuatannya dimana tokoh jane dilukiskan seperti seekor binatang.

c) Majas Asosiasi

(1) Pada kutipa n cerpen "Lalu di sana-sini rumah-rumah orang Eskimo bergundukgunduk seperti es krim panili" majas yang membandingan dua hal yang pada hakikatnya berbeda, tetapi sengaja dianggap sama. Situasi dalam pikiran Jane ketika menggambarkan Alaska yang menurutnya rumah disana begitu kecil-kecil dan penuh.

(2) Berikutnya kutipan yang membandingkan dua hal yang berbeda tetapi sengaja dianggap sama "Kemudian pelan-pelan diciumnya dahi Jane, seperti dahi itu terbuat dari porselin" makna dari kutipan tersebut ialah Marno mencium dahi Jane yang diibaratkan keras seperti porselin.

d) Majas Pleonasme

(1) Pada kutipan cerpen "Mata Jane memandang Marno tajam-tajam" majas yang menggunakan kata-kata secara berlebihan yaitu Tajam-tajam dengan maksud menegaskan arti bahwa jane serius dengan perkataannya kepada Marno. Situasi pada cerpen ini ketika Jane bertanya hal yang serius kepada Marno.

(2) Kutipan berikutnya majas yang menggunakan kata-kata secara berlebihan yaitu "Sinar bulan yang lembut itu membuat seakan-akan bangunan-bangunan itu tertidur dalam kedinginan" menegaskan suasana malam disana begitu sepi dan dingin.

\section{e) Majas Hiperbola}

(1) Pada kutipan cerpen "Beberapa awan menggerombol di sekeliling bulan hingga cahaya bulan jadi suram karenanya" majas yang berupa pernyataan berlebihan dari kenyataannya dengan maksud memberikan kesan mendalam atau meminta perhatian. Makna dari kutipan adalah menggambarkan situasi suasana malam yang sedang mendung hingga tak ada bintang.

(2) Berikutnya kutipan yang berupa perenyataan berlebihan dari kenyataan yaitu "Dilongokknannya kepalanya ke bawah dan satu belantara pencakar langit tertidur di bawahnya" menggambarkan suatu suasana ketika Marno sedang melihat langit didekat jendela lalu melihat gedung yang tinggi.

(3) Selanjutnya yaitu kutipan "rasa senyap dan kosong tiba-tiba terasa merangkak kedalam tubuhnya" makna dari kutipan ini ialah sebuah perasaan sepi sehingga tokoh merasa begitu senyap dan kosong.

f) Majas Metafora

(1) Pada kutipan "Lampu-lampu yang berkelipan di belantara pencakar langit" majas yang mengungkapkan ungkapan secara langsung berupa perbandingan analogis, makna dari kutipan ini adalah menggambarkan lampu yang berkelap-kelip di sebuag gedung yang menjulang tinggi.

(2) Kutipan berikutnya majas yang mengungkapkan ungkapan secara 
langsung berupa perbandingan analogis yaitu "Sebuah pesawat jet terdengar mendesau keras lewat di atas bangunan apartemen Jane" makna dari kutipan ini adalah terdengarnya suara pesawat yang sangat jelas hingga seakan-akan terbang dekat di atas gedung.

\section{Cerpen “Jembatan Yang Ditutup" karya Andrea Alexander Leo \\ 1) Sinopsis Cerpen}

Cerpen ini menceritakan tentangsebuah kota yang mempunyai masalah mengenai pembangunan, yaitu jembatan yang memang sudah tua dan harus cepat diperbaiki. Bila musim kemarau air akan surut tapi jika musim hujan datang air kali pada kota tersebut akan melimpah ruah sampai daratan. Hingga pada musim hujan Dewan Perwakilah Rakyat (DPR) mengadakan sidang khusus untuk membicarakan perbaikan jembatan. Keputasan yang mereka sepakati adalah dengan manaikan harga karcis pasar dan surat akte anak-anak sekolah, surat ijin gedung-gedung bioskop, dan perusahaan baru. Akhirnya jempatan di perbaiki dengan cara memeras rakyat kecil tetapi pembangunan jembatan tak berjalan dengan mulus pada siang hari orang-orang perkerja membangun jembatan tetapi pada malam hari ada pihak yang sengaja membuat jembatan tersebut runtuh di bawa arus air, samapi sekarang jembatan itu masih menyerah pada nasibnya.

\section{2) Gaya Bahasa Cerpen "Jembatan Yang Ditutup"}

a) Majas Repetisi

Pada kalimat "Disamping itu ia sudah tua betul. Karena menurut tahuku, sejak aku ada ia sudah ada juga. Jadi mau tak mau harus akui tuanya itu. Sebagai manusia yang telah tua jembatan itupun sudah mulai rusak-rusak" pada majas ini jelas ada pengulangan kata yaitu kaya 'tua' perulangan kata tersebut artinya menegaskan bahwa memang jembatan pada kota itu benar-benar sudah tua.

\section{b) Majas Simbolik}

(1) Pada kutipan kalimat cerpen "Tidak saja dimusim hujan bahkan juga di musim kemarau. Sekalipun di musim kering ia hanya menggirik dengan kekuatan tak lebih dari derasnya kencing kuda" maksud dari ungkatan ini adalah majas yang melukiskan sesuatu dengan mempergunakan binatang sebagai simbolnya membandingkan keluarnya air pada musim kemarau seperti keluarnya air kencing kuda.

(2) Selanjutnya kutipan cerpen yang melukiskan sesuatu dengan mempergunakan binatang sebagai simbolnya yaitu "dan tamu kami mengangguk-angguk dan mengangguk lagi. Tak ubahnya seperti burung tekutur yang lagi asik bercumbu dengan betinanya dengan bunyi merdu" makna dari kutipan ini adalah reasi seorang tamu yang mengangguk-angguk kepada tuan rumah ketika tuan rumah tersebut dengan bangga menjelaskan bahwa jembatan yang sudah tua tersebut sedang dilalukan perbaikan sehingga di ibaratkan seperti burung tekutur.

c) Majas Ironi

(1) Pada kalimat "Satu golongan hanya yang sungguh senang melihat keadaan semua itu: abang-abang beca. Mereka tertawa-tawa dalam hati, dan bikin jalan berputar-putar dan sewa beca membungbung naik" adalah majas sindiran dengan maksud jika jembatan rusak maka yang senang adalah tukang becak karna dengan begitui rute tujuan penumpang akan lama dan ongkos yang mereka keluarkan akan besar.

(2) Sama halnya dengan kjutipan kalimat cerpen ini "Dan mereka yang menganut paham ekonomi-tanpa-budi yang dimiliki dari dunia barat memuji-muji abang beca, mengatakan, bahwa bangsa Indonesia dari golongan pengendara beca telah menunjukan pengertian sesungguhnya tentang ekonomi, telah sanggup menggunakan suatu momen yang baik" maksud dari majas ini 
adalah momen yang baik untuk para tukang becak mencari uang ketika rakyat kecil ditindas.

\section{d) Majas Pleonasme}

(1) Pada kutipan cerpen " orang-orang di kotaku (yang tak punya leiding) bertambah besar cintanya akan kali itu cinta sebagai seorang jaka yang baru pertama-tama jatuh cinta dan kemudian jadi muak" majas yang menggunakan kata-kata secara berlebihan dengan maksud menegaskan arti suatu kata, makna dari kutipan ini adalah warga yang tak mempunyai leiding menggunakan air kali tersebut dan begitu merasa terbantu tetapi menjadi kesusahan ketika air kali banjir.

(2) Selanjutnya kutipan yang menggunakan kata-kata secara berlebihan dengan maksud menegaskan arti suatu kata yaitu ".....buat apa menulis yang gitugitu kan nanti diketahui oleh kota-kota lain. Dan ini tak lebih dari pada membuaka baju, memperlihatkan tulang yang tak berdaging" makna dari kutipan ini adalah komentar salah satu warga ketika seorang pelukis dan penyair ingin membuat lukisan dan sajak jembatan tersebut akan tetapi warga tersebut tak memperbolehkan karna dianggap membuka aib sendiri sebab jembatan tesebut sudah begitu tua.

(3) Berikutnya kutipan kalimat "bapak telah menghujaninya dengan berbagai pertanyaan pendahuluan" makna dari kutipan ini adalah ketika ada seseorang tamu dari tetangga kota yang ingin melihat pembangunan jembtan tersebut bapak dari tokoh 'aku' merasa begitu bangga lalu bertanya kepada tamu tersebut tentang pembangunan jebatan di kotanya padahal pada kota tersebut taka da jembatan yang diperbaiki.

(4) Berikutnya yakni kutipan cerpen "selanjutnya dapat dibayangkan bagaimana ayah mempropatgandai tamu kami. Jauh lebih hebat dari yang sebenarnya" makna dari kutipan ini adalah ayah dari tokoh 'aku' yang kedatangan tamu dari kota lain dengan sengaja memberikannya beberapa pertanyaan dengan maksud jawabanya sesuai dengan apa yang ia harapkan.

e) Majas Hiperbola

Pada kutipan cerpen "kali ini semua anggota tenggelam dalam khayal masing-masing. Seperti juga jepang yang tenggelam dalam khayal penaklukan dunia kemudian kejatuhan bom atom dan mereka terjaga. Pun anggota-anggota siding terbangun" majas yang berupa pernyataan berlebihan dari kenyataannya dengan maksud memberikan kesan mendalam atau meminta perhatian, makna dari kutipan ini adalah lamunan anggotaanggota siding akan rencana perbaikan jembatan yang harus menggunakan dana besar mereka bingung dari mana dana tersebut.

\section{f) Majas Alegori}

Pada kutipan cerpen "ditaati sungguhsungguh hanya sewaktu menghadapi hantu krisis begini ini, biasa saja bagi mereka yang berbudi kerdil, yang berwatak oportunis yang sama sekali tidak kenal rasa setia sungguh kasihan mereka yang menyangka sanggup menanam agama di dasar jiwa yang sepi budi" majas yangmenyatakan dengan cara lain, melalui kiasan atau penggambaran, makna dari kutipan ini adalah menggambarkan warga kota yang ketakutan bila anak mereka atau gadis di kota tersebut menjadi tumbal untuk pembangunan jembatan tersebut karna mitos yang beredar bila jembatan ingin kokoh maka di bawah jembatan tersebutb ditanami sepala manusia.

\section{g) Majas Sinekdok}

Pada kutipan cerpen "...... dijamin oleh ketua seksi pembangunan, tidak kelihatan batang hidungnya yang melengkung" majas yang menggantikan benda secara keseluruhan atau sebaliknya makna dari kutipan ini adalah menghilangnya ahli bangun- 
bangunan yang perkataannya dijamin oleh seksi bangunan.

\section{h) Majas Sinisme}

Pada kutipan cerpen "dan mereka yang menganut paham ekonomi-tanpa-budi yang dimiliki dari dunia barat memujimuji abang beca telah menunjukan mengertian sesungguhnya tentang ekonomi telah sanggup menggunakan suatu momen yang baik" majas yang menyatakan sindiran secara langsung makna dari kutipan ini adalah sebuah keadaan pembangunan yang gagal maka para tukang becak senang karna tarif mereka akan naik akibat jalan alternatif tersebut tidak bisa dilewati.

\section{Cerpen "Kubur" karya S. N. Ratmana}

\section{1) Sinopsis Cerpen}

Sebuah keluarga yang berselisih tentang paham anut agama mereka sebagian anak menganut islam tetapi tidak taat dan sebagian lagi sangat agamis. Konflik ini bermula dengan salah satu putra mereka ingin mengkijing (tembok kuburan) ibu mereka yang sudah wafat hal ini di lakukan karna bermaksud memuliakan almarhum ibu mereka agar kuburan tersebut tidak ditumpang tindih oleh lainnya tetapi ayah mereka dan putra ketiga keberatan karna dalam agama islam kijing itu diharamkan bila ingin bermaksud memuliakan ibu mereka tidak harus dengan cara seperti itu. Ahirnya putra pertama bersikeras mengkijing, begitu mengetahui makam ibunya dikijing putra ketiga membongkar makam tersebut dan keduanya merasa sangat marah, tidak diketahui apakah putra pertama masih punya kehendak untuk membangun kembali kubur itu atau tidak yang jelas hubungan keluarga tersebut renggang.

\section{2) Gaya Bahasa Cerpen "Kubur" \\ a) Majas Metafora}

Pada kalimat "Djo, kau rupanya ingin jadi pahlawan pembela ayah dalam segala hal tanpa pertimbangan apakah dengan demikian kau sudah jadi seorang tokoh reaksioner" ungkapan ini adalah majas yang mengandung perbandingan analogis secara langsung. Telihat dari kata reaksioner yang artinya sikap yang serba aktif dan reatif dan menanggapi suatu keadaan.

\section{b) Majas Paradoks}

Pada kalimat "Sama sekali bukan tindakan destruktif, sangkal Mas Hardjo cepat-cepat, sebagaimana penghancuran berhala-berhala yang dilakukan oleh Nabi Muhammad juga tidak disebut tindakan destruktif. Malah sebaliknya konstruktif. Membangun iman. Ibuku terdesak karenanya. Kemudian dengan nada yang merendah beliau berkata: engkau tidak akan berhasil memaksakan pahammu kepada orang lain dengan kekerasan. Lebih baik tenangkan dulu pikiranmu, Djo" ungkapan majas yang bertentangan antara ungkapan dan fakta yang ada terjadi pergulatan batin karna pada kenyataanya tidak sesuai dengan apa yang diinginkan.

c) Majas Retorik

(1) Pada kalimat "Tidak kuketahui apakah Mas Hari masih punya kehendak untuk membangun kembali kubur itu. Juga tidak kuketahui bagaimana sikap putraputra paman lainnya seperti Mbak Ati dan Mbak Ning" ungkapan majas ini adalah ungkapan kalimat tanya namun tak memerlukan jawaban terlihat dari tokoh Mbak Ning dan Mbak Ati yang pastinya sedih karena kedua kakaknya berseteru.

(2) Selanjutnya ungkapan kalimat tanya namun tak memerlukan jawaban terlihat pada kalimat "begitukah cara kalian menghormati orang tua? Baru pada umur enam puluh lima tahun inilah aku mendapat tamparan yang begitu hebat" makna dari kutipan ini adalah balasan surat Ayah kepada Mas Hari dan Mas Harto bahwa Ayah tak menyangka anaknya akan tega bersikap demikian kepada orang tuanya sendiri.

(3) Berikutnya ungkapan kalimat tanya namun tidak memerlukan jawan terlihat dari kutipan "tapi ingatlah orang tua kita 
ada dua. Patutkah kalau kita menghormati yang satu dengan cara melukai yang lain?" makna dari kutipan ini adalah isi dari surat Mas Hardjo untuk Mas Hari dan Mas Harto bahwasannya Mas Hardjo ingin mengungkapkan Bahwa memuliakan orang tua dengan tidak memperdulikan orang tua yang masih hidup sama sekali bukan tindakan yang benar.

d) Majas Pleonasme

(1) Pada kutipan kalimat “.....secara tidak sengaja dia mendengar ucapan istri Mas Hari yang mengecam dengan tajam sikap anggota-anggota keluarga paman" majas yang menggunakan kata-kata secara berlebihan dengan maksud menegaskan arti suatu kata makna dari kutipan ini adalah Mas Harto yang mendengar ucapan istri Mas Hari yang tidak senang jika suaminya memberikan bantuan materi kepada keluarganya.

(2) Selanjutnya kutipan yang menggunakan kata-kata secara berlebihan dengan maksud menegaskan arti suatu kata terdapat pada “....dengan nada yang penuh kemarahan kemudian dia menyurati paman" makna dari kutipan ini adalah Mas Hari mengirim surat untuk ayahnya dengan tulisan yang bernada marah mengenai larangan ayahnya untuk tidak mengkijing makan ibunya.

(3) Berikutnya kutipan "sudah bukan masanya lagi ayah mendikte kami" makna dari kutipan ini adalah sebuah isi dari surat Mas Hari untuk ayahnya yang merasa bahwa ayahnya selalu mengatur hidup anaknya.

\section{e) Majas Simbolik}

Pada kutipan cerpen "....sekarang datang pula kakakmu membawa keluhan-keluhan yang beratnya seribu kali gajah" majas yang melukiskan sesuatu dengan mempergunakan binatang sebagai simbol atau lambang makna dari kutipan ini adalah ungkapan ketidak senangan istri Mas Hari yang membandingkan bahwa beban keluhan masalah kakak Mas Hari itu beratnya seperti gajah.

\section{f) Majas Sarkasme}

Pada kutipan cerpen "sungguh, demi Tuhan, demi setan! Bukan maksud saya mennggurui Ayah" majas sindiran yang paling kasar makna dari kutipan ini adalah isi surat dari Mas Harjo kepada Ayah yang mengatkan bahwa dia tak bermaksud menggurui Ayah dengan tindakan mas Hari yang mengkijing makan ibunya.

\section{g) Majas Alegori}

Pada kutipan cerpen "....sebalikya bi, membiarkan tetap berdirinya kubur itu berarti saya membiarkan tegaknya lambang keangkuhan seorang anak terhadap bapak, kesombongan seorang anak akan kebenaran pendapatnya sendiri" Majas yang menyatakan dengan cara lain, melalui kiasan atau penggambaran makna dari kutipan ini adalah percakapan Mas Hardjo bersama Bibi yang bersi keras ingin meruntuhkan kembali kuburan tersebut yang sudah dikijing oleh Mas Hari karena Mas Hardjo begitu tidak setuju karna kakak mereka berdua telah melukai hati Ayahnya sendiri dengansikap angkuh dan sombong yang tidak mendengarkan perintahnya.

\section{Cerpen "Kelimutu" karya Titie Said}

\section{1) Sinopsis Cerpen}

Menceritakan seorang wanita bernama Messi. Messi ini sering membawa anaknya ke suatu tempat yaitu Danau Kelimutu, untuk sekedar merenung sekaligus mendo'akan suaminya yang meninggal akibat pemberontakan terhadap kompeni. Konflik dalam cerita berawal dari rasa penasaran Tabeta, anak Messi, terhadap warna salah satu air danau yang merah. Dia penasaran karena telah mendengar bahwa ayahnya di buang ke danau tersebut akibat berkhianat, Messi marah dan teringat kenangan sepuluh tahun ke belakang saat Messi masih bersama suaminya. Montero berencana melakukan pemberontakan yang akan dilakukannya dan teman-temannya. 
Montero tertangkap oleh kompeni dia disiksa karena tidak mengaku akan keberadaan pimpinannya Montero terus bungkam akhirnya kompeni mengancam akan mengganggu Messi apabila Montero terus merahasiakan tempat pemimpinnya lalu Montero berjanji kepada kompeni bahwa dia akan mengatakan tempat pemimpinnya karena tidak kuasa melihat istrinya diganggu Messi merasa dia telah menyebabkan suaminya akan berkhianat. Siasat yang dilakukan Montero saat memberitahukan nama pemimpinnya sehingga dia berhasil membunuh tiga kompeni tanpa harus berkhianat, namun akhirnya dia sendiri terbunuh. Penyebaran fitnah oleh kompeni kepada penduduk bahwa Montero berkhianat dan mayatnya dibuang ke Danau Kelimutu. Akhirnya Messi memutuskan untuk hidup menyendiri di dekat Danau kelimutu untuk menghindari desas-desus kebohongan terhadap suaminya. Tekad Messi untuk membesarkan anaknya di tempat yang jauh dari kompeni dan selalu diajarkan untuk memuliakan bapaknya. Janji Messi bahwa dia akan menceritakan kejadian sebenarnya tentang Montero kepada anaknya, Tabeta.

\section{2) Gaya Bahasa Cerpen "Kelimutu"}

a) Majas Sarkasme

(1) Pada kalimat "Anjing! kau lihat isterimu cantik. Kamu sayang padanya. Tapi lihat tuan yang memegang itu akan menciumnya Diam!" ungkapan seperti ini adalah majas sindiran yang paling kasar dan diucapkan orang yang sedang marah. Terlihat dari kata umpatan binatang yaitu "Anjing!" hal ini menjelaskan bahwa Montero sangat marah karna apa yang kompeni lakukan kepada Messi istrinya.

(2) Selanjutnya ungkapan sindiran paling kasar terdapat pada kutipan "Diam! Kenapa kau bilang begitu" makna dari kutipan ini adalah kemaran Messi terhadap Tabeta anaknya yang berbicara bahwa ayahnya adalah seorang penghianat.
(3) Berikutnya kutipan "..lekas kataka Anjing!" makna dari kutipan ini adalah kompeni yang marah ketika megintrogasi Montero yang masih saja bungkam.

\section{b) Majas Antiklimaks}

Pada kalimat "Tiga hari messi mencari Montero dirumah famili-familinya, di ladang dan dipengembalaan. Tidak ditemukan. Rumah messi digeledah kompeni. Messi dibentak tapi sepatah katapun tak menjawab" ungkapan ini adalah majas yang menyatakan beberapa hal berturut-turut yang makin lama makin menurun. Terlihat dari penggalan kalimat "di rumah famili" "di ladang" dan "dipengembalaan" penjabaran runtut dari yang terbesar hingga menurun sampai yang terkecil.

c) Majas Metafora

(1) Pada kalimat "Lalu komandan bermata juling dan perut besar menari dengan gerak lucu" ungkapan ini adalah majassebagai lukisan yang berdasarkan persamaan atau perbandingan makna dari kutipan ini adalah menggambarkian kompeni yang sedang mabuk dan tergoda oleh kecantikan Messi sehingga dikiaskan dengan mata juling.

(2) Selanjutnya majas yang mengungkapkan ungkapan secara langsung berupa perbandingan analogis terdapat pada kutipan “......seperti jantan lainnya tak takut berkelahi membela Flores" makna dari kutiapan ini adalah ucapan Montero bahwa dia adalah lakilaki yang tak takut untuk berkelahi melawan kompeni demi kota Flores.

(3) Berikutnya kutiapan "....dan kembali cambuk menari dibadannya yang kurus" makna dari kutipan ini adalah Montero di cambuk oleh kompeni di depan Messi istrinya agar dia mengaku dimana pimpinam pemberontak bersembunyi.

(4) Berikutnya kutipan "....dia harus menelan tuduhan yang berat" makna dari kutipan ini adalah ketidakberdayaan Messi kepada keadaan dan berita yang sudah 
menyebar dikalangan masyarat bahwa suaminya telah berhianat dan dia harus menerima tuduhan yang tidak benar itu.

d) Majas Pleonasme

(1) Pada kutipan cerpen "panas rembang petang masih membakar" majas yang menggunakan kata-kata secara berlebihan dengan maksud menegaskan arti suatu kata makna dari kutipan ini adalah suasana di sebuah desa pada siang hari yang cerah dan panas.

(2) Selanjutnya kutipan yang menggunakan kata-kata secara berlebihan dengan maksud menegaskan arti suatu kata terdapan pada kalimat "dari jauh seorang tua berteriak menegur" makna dari kutipan ini adalah ketika Messi dan Tabeta berjalan menuju danau Kelimutu mereka ditegur oleh seseorang neneknenek.

(3) Berikutnya kutipan cerpen "dari tangga rumah, Messi menjenguk bekas tangsi yang hangus" makna dari kutipan ini adalah setelah acara papeda yang diselingi dengan suara tembakan pada malam itu dipagi hari Messi melihat bekas tangsi yang hangus dan suaminyapun belum juga pulang maka kekhawatiran Messi bertambah.

(4) Berikutnya kutipan cerpen "Messi menyingkir di pojok" makna dari kutipan ini adalah keadaan dimana Messi tak tahan mel;ihat Montero disiksa kompeni dia diam disudut pojok ruangan tersebut.

e) Majas Asosiasi

(1) Pada kutipan cerpen "...dan kompenikompeni itu memukulnya lagi seperti orang membelah kayu" majas perumpamaan membandingan dua hal yang pada hakikatnya berbeda, tetapi sengaja dianggap sama makna dari kutipan ini adalah para kompeni yang terus menyiksa Montero yang begitu keras sehimgga diibaratkan seper membelah kayu.

(2) Selanjutnya kutipan cerpen yang membandingkan dua hal yang berbeda tetapi sengaja dianggap sama terdapat pada kutipan "....hatinya berdentang. Mengapa Montero berhianat" makna dari kutipan ini adalah sebuah perasaan kaget Messi yang tidak percaya bahwa suaminya akan berhianat sehingga diibaratkan hatinya berdentang.

\section{f) Majas Sinisme}

Pada kutipan cerpen "tutup mulutmu! Aku akan mengatakan jika kau melepaskan ikatanku dulu" ungkapan kalimat ini majas yang menyatakan sindiran secara langsung makna dari kutipan tersebut aadalah permintaan Montero kepada kompeni agar dia melepaskan ikatannya lalu dia akan memberitahukan dimana pemimpin pemberontak berada.

g) Majas Hiperbola

Pada kutipan cerpen "danau kelimutu masih beriak tenang. Matahari terbenam sama sekali. Airnya merah, hijau dan hijau muda bermain dengan cahaya kegelapan mengantar messi pulang" majas yang berupa pernyataan berlebihan dari kenyataannya dengan maksud memberikan kesan mendalam atau meminta perhatian makna dari kutipan tersebut adalah suasan petang danau kelimutu yang diiringi kepergian Messi pulang kerumahnya.

\section{Analisis Gaya Bahasa Cerpen Angkatan 2000 \\ Cerpen "Jalan Gelap Langit Terang" karya Abdul Wachid B.S \\ 1) Sinopsis Cerpen}

Cerpen ini menceritakan seorang tokoh Hayati yang menikah dengan laki-laki bernama Basyar tetapi dalam pernikahan itu ia tak merasa bahagia karna Hayati menikah pada umur yang sangat muda yaitu delapan belas tahun. Basyar lelaki yang dulu ia kagumi kini tak lagi sempurna dimatanya karna Basyar dua dengan satu orang anak, Hayati dan Basyar tinggal beda kota karna Hayati melanjutkan kuliah di Jogja. Di Jogja ia memiliki kekasih bernama Mas Jati kisah kasih ia lalui dengan Mas Jati tapi Hayati tidak bisa melupakan cahaya Basya 
suaminya ia kehilangan arah bingung pada jalan hidupnya untuk menentukan cahaya mana yang akan ia pilih karna sekarang cahaya tersebut gelap.

\section{2) Gaya bahasa Cerpen "Jalan Gelap Langit Terang"}

a) Majas Hiperbola

(1) Pada kutipan cerpen "Hayati membayangkan, kapan sang Pangeran akan menjemputnya dari dunia yang sepi ini, dunia yang membosankan, dunia yang memenjara. Barangkali inilah saatnya" adalah majas yang berupa pernyataan berlebihan dari kenyataannya dengan maksud memberikan kesan mendalam atau meminta perhatian. Terlihat pada maksud dari ungkapan tersebut bahwa hayati sangat mendambakan sosok lakilaki yang diibaratkan pangeran untuk menemaninya dan hanya merasa bahwa hidupnya terasa tak bebas.

(2) Selanjutnya kutipan yang berupa pernyataan berlebihan dari kenyataannya dengan maksud memberikan kesan mendalam atau meminta perhatian terdapat pada kutipan "namun pada saat Mas Jati menjadi cahaya di kegelapan hidup Hayati dengan mengajaknya memilih kejelasan dari percintaan ini, justru Hayati tak mampu lagi melukis wajah Mas Jati di dalam angan, perasaan, dan pikirannya" makna dari kutipan ini adalah sebuah perasaan hayati perasaan bimbang karna walaupun ia berselingkuh dengan Mas Jati dia tak bisa memilih yang hanya ia ingat dalam hatinya hanya Basyar.

(3) Berikutnya kutipan "Langit lalu lintas, tertutup korden malam. Itu tandanya pertunjukan dari Tuhan telah usai" makna dari kutipan ini adalah suasana malam tetapi Hayati masih belum bisa memilih dia hanya terkapar dalam pikirannya.

b) Majas Sarkasme

(1) Pada kutipan cerpen "Dan kini aku harus menjadi saksi atas perceraianmu, dengan berbuah anak lelaki satu. Astaga! Dosa apalagi ini, Gusti!" majas sindiran yang mengungkapkan sebuah perasaan emosi yang tak terkontol dan perasaan marah hayati terhadap hidupnya karna menerima kenyataan bahwa dia harus menikah dengan Basyar ketika status Basyar dudan dan mempunyai satu anak.

1) Selanjutnya kutipan cerpen yamg mengungkapkan ungkapan yang kasar "Anak gadis, kok kayak begini kemprohnya! Ya ampun, Tuhan!” makna dari kutipan ini adalah ibu hayati yang setiap malam minggu datang kerumah dan melihat keadaan rumah yang berantakan tak diurus oleh hayati.

2) Berikutnya kutipan "Kamu harus pulang! Harus!" makna dari kutipan tersebut ialah ungkapan marah Basyar kepada istrinya Hayati tak mau pulang dari Jogja yang sedang kuliah.

Berikutnya kutipan cerpen "Aku tak mau peduli!" makna dari kutipan ini adalah pada saat Hayati ditelfon oleh Basyar agar pulang ia menjawab tidak mau maka Basyar marah dan tidak mau tau bahwa Hayati harus pulang.

\section{c) Majas Klimaks}

Pada kitipan cerpen "Aku menurut. Memang aku selalu menurut, tanpa kata, seperti kepada Ibuku, Bapakku, dan para Guru di sekolah" majas yang majas yang menyatakan beberapa hal berturut turut dan makin lama makin meningkat terlihat pada kutipan kepada Ibuku, Baoakku, dan Para Guruku.

\section{d) Majas Pleonasme}

(1) Pada kutipan cerpen "cinta dalam eksistensi dan wujudnya yang paling dini dan akhir ialah kekaguman terhadap keberadaan sang Kekasih" majas yang menggunakan kata-kata secara berlebihan dengan maksud menegaskan arti suatu kata makna dari kutipan tersebut adalah menyatakan bahwa kemunculan yang paling dasar atau awal dan ahir dari rasa cinta adalah 
kesan kekaguman terhadap seorang kekasih

(2) Selanjutnya kutipan yang menggunakan kata-kata secara berlebihan dengan maksud menegaskan arti suatu kata terdapat pada kutipan “.....mata Basyar berbinar" makna dari kutipan ini adalah mata basyar yang terlihat menyakinkan ketika berjanji kepada Hayati bahwa mereka akan bahagia kelak jika menikah nanti.

(3) Berikutnya kutipan cerpen “....berharap ia jadi pangeran yang akan membawaku meninggalkan neraka rumah tangga ibuku" makna dari kutipan ini adalah dulu Hayati pernah berharap bahwa Basyar akan menjadi seorang pria yang akan membanya pada kehidupa yang lebih baik dari rumah tangga orang tuanya tetapi kini ia menikah dengan Basyar yang sudah duda.

(4) Berikutnya kutipan cerpen "Justru padaku, yang anak perempuannya, dan satu-satunya, ibu selalu menganggapku sepi" ibu Hayati yang tak memerdulikan perkataan Hayati dan lebih memercayai setiap perkataan Basyar yang pandai merebut hati mertuanya.

(5) Berikutnya kutipan cerpen "dua cahaya itu begitu menyilaukan mata dan hatinya. Dan, Hayati tak kuasa" makna dari kutipan ini adalah dua sosok lelaki yang memberinya cinta sehingga membuat Hayati begi bingung untuk menetapkan hatinya.

(6) Berikutnya kutipan "Mengapa jalan gelap padahal langit terang! Mengapa cahaya itu justru merabunkan mataku! Mengapa..." makna dari kutipan ini adalah ungkapan Hayati dalam pikirannya merasa bingung untu memilih keputusan dan justru membuatnya bingung dan tak tau harus memilih siapa.

(7) Berikutnya kutipan "Hayati terkapar dengan luka" makna dari kutipan ini adalah Hayati hanya bisa terdiam dengan sedih karna tidak bisa menemukan pilihan untuk hidupnya. e) Majas Metafora

(1) Pada kutipan cerpen “.....kau adalah cintaku, dan cinta adalah cahaya" majas yang mengungkapkan ungkapan secara langsung berupa perbandingan analogis makna dari kutipan ini adalah tokoh 'aku' yang mengibarakan cinta seperti cahaya,

(2) Selanjutnya kutipan cerpen yang mengungkapkan ungkapan secara langsung berupa perbandingan analogis terdapat pada kutipan "Ia merasa dirinya menjelma menjadi seorang dewi, yang diperempuankan oleh lima lelaki Pandawa" makna dari kutipan ini adalah Hayati yang dibuat bingung oleh dua lelaki yang dicintainya ketika harus memilih sehingga dia diibaratkan sebagai dewi yang di rebutkan pandawa.

\section{f) Majas Paradoks}

Pada kutipan cerpen "Aku menurut, tapi cuma di depan mata. Hatiku berontak. Pikiranku membatu" majas yang mengandung pertentangan antara pernyataan dan fakta yang ada makna dari kutipan ini adalah pada saat Hayati menerima menikah dengan Basyar dia merasa tak siap dan tak mau menikah dengan Basyar.

\section{Cerpen "Ada Yang Menangis Sepanjang Hari" karya Agus Noor 1) Sinopsis Cerpen}

Cerpen ini menceritakan tentang suara tangisan yang terdengar tiap malam pada sebuah perkampungan yang dimana masyarakat sekitar kampung tersebut mengira tangisan itu suara Kumirah yang menangisi kepergian suaminya yang mati dibakar masa karena mencuri jagung rebus.Tetapitangisan tersebut sbukan hanya terdengar dikampung itu saja melainkan tetangga kampong juga juga ikut mendengar suara tangisan tersebut hingga beberapa hari tangisan itu sampai pada ke kecamatan lalu kabupaten hingga kota dan telingan Presiden juga tangisan sangat pilu dan menyayat hati sampai sekarang ntah tangisan siapa itu. 
2) Gaya Bahasa Cerpen"Ada Yang Menangis Sepanjang Hari”

a) Majas Simbolik

Pada kutipan cerpen "Tangis itu jadi mirip cakar kucing yang menggarukgaruk dinding rumah. Bagai mimpi buruk yang menggerayangi syaraf dan minta diperhatikan" majas yang melukiskan sesuatu dengan mempergunakan benda, binatang, atau tumbuhan sebagai simbol atau lambang. Terdapat pada makna tangis itu jadi mirip cakaran kucing artinya membandingan tangisan tokoh perempuan yang diduga menangis itu begitu menyedihkan seperti menginginkan orang-oang sekitar mengetahui.

b) Majas Personifikasi

Pada kutipan cerpen "Tangisan itu bagai mampu meredakan deru ombak hingga laut terlihat bening dan datar berkilauan di bawah cahaya bulan yang keperakan" majas yang membandingkan bendabenda tak bernyawa seolah-olah mempunyai sifat seperti manusia. Tedapat pada makna tangisan itu mampu meredakan deru ombak artinya ketika orang-orang kampung sekitar mendengar tangisan tersebut mereka langsung merasa iba dan kasihan karena tangisan tersebut begitu menyedihkan.

c) Majas Hiperbola

(1) Pada kutipan cerpen "Semesta begitu hening. Tak ada suara selain tangis yang penuh kesedihan itu. Tangis yang terus mengalun mengalir hingga galaksigalaksi paling jauh" majas yang berupa pernyataan berlebihan dari kenyataannya dengan maksud memberikan kesan mendalam atau meminta perhatian. Pada makna tangis yang terus mengalir hingga galaksigalaksi yang paling jauh itu maksudnya tangisan kesedihan itu mampu terdengar hingga ke kota sampai terdengar ditelinga presiden.

(2) Berikutnya kutipan yang berupa pernyataan berlebihan dari kenyataannya dengan maksud memberikan kesan mendalam atau meminta perhatian yaitu "Tangisan itu seperti kesedihan yang mengapung di udara. Menyelesup ke rumah-rumah kampung pinggir kota itu" makna dari kutipan ini menggambarkan tangisan tersebut terdengar sampai tetangga kampong.

(3) Selanjutnya kutipan "Pada hari ke-17 seluruh kota sudah digelisahkan tangisan itu" makna dari kutipan ini adalah karna seringnya terdengar tangisan tersebut sampai hari ke 17 satu kota telah mendengar dan mengetahui tangisan tersebut.

(4) Selanjutnya kutipan yang berupa pernyataan berlebihan dari kenyataannya dengan maksud memberikan kesan mendalam atau meminta perhatian yaitu "Tangisan itu bagai mengalir sepanjang jalan sepanjang sungai sepanjang hari sepanjang malam, melintasi perbukitan kering, merayap di hamparan sawah yang tergenang banjir dan terdengar gemanya yang panjang hingga ngarai dan lembah yang kelabu sampai ke dusun-dusun paling jauh di pedalaman" makna dari kutipan ini adalah begitu terdengar terus sampai ke pelosok pedesaan.

(5) Kutipan selanjutnya yaitu "Tangis itu menyelusup lewat celah jendela, dan membuat Presiden tergeragap dari kantuknya" makna dari kutipan tersebut adalah ketidaktahuan presiden akan masalah sosial pada masyarat yang bergulir seperti tangisan tersebut mengibaratkan sebuah tangisan rakyat miskin yang kurang diperhatikan oleh pemerintah.

(6) Berikutnya yaitu kutipan "Segala suara bagai meredup dan mengendap dalam gelap. Semesta terkesima dan seketika terdiam" makna pada kutipan tersebut adalah ketika melihat sebuah masalah soaial pada rakyat semua hanya diam dan tak ada tindakan. 


\section{d) Majas Sarkasme}

Pada kutipan cerpen "Suruh keparat itu berhenti menangis! sergah warga lainnya" majas yang diungkapkan oleh tetangga atau warga yang kesal akibat tangisan tersebut karena masyarakat sekitar merasa terganggu oleh tangisan yang belum diketahui darimana asalusulnya.

e) Majas Asosiasi

(1) Pada kutipan cerpen "Kadang tangis itu terdengar seperti suara tangis bayi yang rewel kelaparan. Kadang seperti suara perempuan terisak setelah digampar suaminya yang mabok. Kadang terisak panjang. Kadang seperti keluhan. Kadang seperti erang binatang sekarat. Kadang seperti sayatan panjang yang mengiris malam" majas yang membandingan dua hal yang pada hakikatnya berbeda, tetapi sengaja dianggap sama, pada kutipan ini menggambarkan bahwa suara tangisan tersebut setiap malamnya berubahrubah tak menentu.

(2) Berikutnya kutipan yang membandingkan dua hal yang pada hakikatnya berbeda, tetapi sengaja dianggap sama yaitu "Tangis itu seperti air banjir yang meluber ke mana-mana" makna dari kutipan ini adalah karna sering mendengar suara tangisan tersebut tanpa tahu orang yang menangis hanya bisa mengira-ngira dan terdengar kampong sebelah sehingga dikiaskan tangisasn tersebut seperti air banjir yang meluber kemana-mana.

(3) Selanjutnya kutipan "Tangisan itu bagai mampu meredakan deru ombak hingga laut terlihat bening dan datar berkilauan di bawah cahaya bulan yang keperakan" makna dari kutipan ini adalah tangisan tersebut mampu membuat keadaan yang ramai menjadai diam karna tangisan tersebut memberikan perhatian yang lebih.

(4) Pada kutipan cerpen "Kadang tangis itu terdengar seperti suara tangis bayi yang rewel kelaparan. Kadang seperti suara perempuan terisak setelah digampar suaminya yang mabok. Kadang terisak panjang. Kadang seperti keluhan. Kadang seperti erang binatang sekarat. Kadang seperti sayatan panjang yang mengiris malam" majas yang membandingan dua hal yang pada hakikatnya berbeda, tetapi sengaja dianggap sama, pada kutipan ini menggambarkan bahwa suara tangisan tersebut setiap malamnya berubahrubah tak menentu.

(5) Berikutnya kutipan yang membandingkan dua hal yang pada hakikatnya berbeda, tetapi sengaja dianggap sama yaitu "Tangis itu seperti air banjir yang meluber ke mana-mana" makna dari kutipan ini adalah karna sering mendengar suara tangisan tersebut tanpa tahu orang yang menangis hanya bisa mengira-ngira dan terdengar kampong sebelah sehingga dikiaskan tangisasn tersebut seperti air banjir yang meluber kemana-mana.

(6) Selanjutnya kutipan "Tangisan itu bagai mampu meredakan deru ombak hingga laut terlihat bening dan datar berkilauan di bawah cahaya bulan yang keperakan" makna dari kutipan ini adalah tangisan tersebut mampu membuat keadaan yang ramai menjadai diam karna tangisan tersebut memberikan perhatian yang lebih.

\section{f) Majas Sinisme}

Pada kutipan cerpen "Pelan Presiden membuka jendela, tapi yang tampak hanya bayangan pagar yang baru direhab menghabiskan 22,5 Milyar" majas yang yang menyatakan si diran secara langsung makna dari kutipan tersebut adalah ketika presiden melihat masalah social pada rakyatnya ia hanya melihat dana yang sudah dihabiskan begitu banyak.

Cerpen "Rumah-Rumah Menghadap Jalan" karya Raudal Tanjung Banua

\section{1) Sinopsis Cerpen}

Cerpen ini memceritakan tentang seorang Kakek Khaidir yang kesepian karna semua 
anak-anaknya meninggalkannya untuk merantau istrinya sudah meninggal dunia. Dan kini dia tinggal bersama cucunya di perkampungan tersebut Kakek Khaidir sering bercerita kepada cuicunya tentang rumah-rumah yang menghadap jalan. Semakin Kakek menceritakan atau bisa dibilang Kakek berkeluh kesah tentang orang-orang yang pergi merantau semakin cucunya merasa penasaran akan kota-kota besar tersebut. Akhirnya dia pergi ke kota untuk merantau dan mencari pekerjaan Kakek ditinggal sendiri di rumah tanpa teman satupun. Hingga suatu hari ketika cucu Kakek tersebut sedang beristirah sambil meneguk kopinya dia melihat Kakek Khaidir yang masuk berita televisi sedang memanjat pohondan tak mau turun karena menurut Kakek dia bisa melihat rumah yang tak menghadap jalan lalu cucunya berfikir akan pulang dan menemui Kakek.

\section{2) Gaya Bahasa Cerpen "Rumah-rumah menghadap jalan"}

a) Majas Asosiasi

(1) Pada kutipan cerpen "ia mendengar bunyi seruling, jauh di belakang, seperti memanggil-manggil" majas yang membandingan dua hal yang pada hakikatnya berbeda, tetapi sengaja dianggap sama makna dari kutipan tersebut adalah menjelaskan sebuah rasa rindu akan suasana rumah yang dulu dimana di belakang rumah tersebut ada seseorang yang mengembala kerbau dan biasa memainkan suling hingga diibaratkan suling tersebut seperti memanggil-manggil.

(2) Selanjutnya kutipan cerpen yang membandingan dua hal yang pada hakikatnya berbeda, tetapi sengaja dianggap sama terdapat pada kutipan cerpen "....kapal batubara yang terlihat seperti pulau hitam" makna dari kutipan tersebut adalah membandingkan kapal yang mengangkut batu bara diibaratkan seperti sebuah pulai yang berwara hitam.

b) Majas Pleonasme
(1) Pada kutipan cerpen "Tentu dengan harga tanah yang lantas mengharu-biru" majas yang yang menggunakan katakata secara berlebihan dengan maksud menegaskan arti suatu kata makna dari kutipan tersebut adalah tanah tanah kosong tepat di belakang rumah tersebut yang biasa kerbau mencari rumput kini sudah dibuat jalan dan rumah, rumahrumah tersebut djual dengan harga yang mahal.

(2) Selanjutnya kutipan cerpen yang menggunakan kata-kata secara berlebihan dengan maksud menegaskan arti suatu kata terdapat pada kutipan "dan dadanya akan berdebar saat item cabe merah keriting disebutkan" makna kutipan tersebut adalah petani cabai setiap kali menonton televisi lalu harga cabai disebutkan dia akan merasa hawatir bila mana nanti harga cabai akan turun lagi sementara harga pupuk terus naik.

(3) Berikutnya kutipan "Mungkin aku terperangkap begitu jauh dalam labirin ungkapan yang mengharu-biru itu" makna dari kutipan tersebut adaah cucu Kakek Khaidir penasaran dengan cerita kakek tentang orang yang pergi dengan masing-masing tujuan mereka untuk sukses.

(4) Berikutnya kutpan "Sebaliknya, truktruk bak terbuka semakin merajalela, tidak saja mengeruk pasir dan kerikil" makna dari kutipan tersebut adalah pedati yang biasa Kakek Khaidir pakai untuk mengangkut pasir di sungai kini sudah tak terpakai lagi karena sudah banyak truk yang akan mengangkut pasir maupun tanah.

(5) Berikutnya kutipan "Dan ungkapan kakek pun kekal di setiap langkah" makna dari kutipan tersebut adalah tokoh 'aku' yang ikut ke kota bersama kernet bis selalu memingat ucapan Kakek Khaidir tentang kota-kota yang belum dia jumpai.

c) Majas Personifikasi 
1) Pada kutipan cerpen "dari jendela bis yang melaju kulihat juga bulan pucat ikut berlari bersama kami” maas yang yang membandingkan benda-benda tak bernyawa seolah-olah mempunyai sifat seperti manusia makna dari kutipan tersebut adalah tokoh 'aku' yang ikut menjadi kernet bis lalu melihat keluar jendela bis pada malam hari ia membandingkan bahwa bulan ikut berlari bersama bis.

2) Selanjutnya kutipan yang membandingkan benda-benda tak bernyawa seolah-olah mempunyai sifat seperti manusia terdapat pada kutipan cerpen "kepulan asap di cerobong lokomotif yang terus menjerit dan melenguh sampai jauh" makna dari kutipan tersebut adalah pada saat tokoh'aku' naik kereta api untuk menuju kekota dia melihat rumahrumah yang membelakangi kereta api dengan kepulan asap pada rumah tersebut dengan besamaan keluarnya asap pada cerobong kereta diibaratkan sedang menjerit.

d) Majas Retorik

Pada kutipan cerpen "Jadi, adakah di dunia ini sebuah kampung di mana rumah-rumahnya tidak menghadap jalan?" majas yang berupa kalimat tanya namun tak memerlukan jawaban makna dari kutipan tersebut adalah tokoh 'aku' yang melihat setiap rumah pasti selalu menghadap jalan.

\section{e) Majas Tautologi}

Pada kutipan cerpen "Laki-laki itu, lakilaki itu, tidak salah lagi, kakekku" majas yang majas penegasan dengan mengulang beberapa kali sebuah kata dalam sebuah kalimat dengan maksud menegaskan makna dari kutipan tersebut adalah tokoh 'aku' yang melihat Kakek Khaidir yang ada di berita televisi.

\section{Cerpen "Laki-Laki" karya Abidah el khalaeqy}

1) Sinopsis Cerpen
Cerpen ini menceritakan tentang lakilaki bernama prakoso yang didapati istrinya telah berselingkuh tetapi prakoso terus saja mengelak disaat melati mengintrogasinya bahkan ketika semua bukti-bukti peselingkuhan itu ada didepan mata prakoso masih saja mengelak. Kesabaran melati telah habis karna prakoso terus saja mengelak tetapi itu tak membuat prakoso untuk mengakuinya, dalam keadaan penuh emosi lantaran melati terus menyudutkan tuduhan yang memang benar adanya prakoso emosi lalu memukul-mukul melati istrinya sendiri karna melati mengacam akan menyebarkan foto-foto tersebut ke tempat dia bekerja. Prakoso menjadi begitu tega dan kejam memukul melati hingga tewas dalam kejaran polisi dia begitu ketakutan dan putus asa mencari tempat persembunyian yang nyaman untuk hingga ia berfikir untuk ketempat selingkuhannya itu tetapi hungga sampai tempat tersebut ia mengurungkan niatnya lalu pergi.

\section{2) Gaya Bahasa Cerpen "Laki-Laki"}

\section{a) Majas Paradoks}

Pada kutipan "Jelas aku berbeda dengan mereka. Mereka berambut keriting dan rambutku lurus. Ini tandanya jiwaku juga lurus? moralku juga lurus? Apa kau belum pernah memperhatikan rambutku?" majas yang mengandung pertentangan antara pernyataan dan fakta yang ada, makna dari kutipan tersebut bahwa tokoh prakoso berbohong kepada istrinya.

b) Majas Simbolik

(1) Pada kutipan cerpen "Prakoso mencoba melunakkan situasi dengan meraih Melati. Tetapi Melati bukan Melati kalau tidak Melati. Bertameng duri, ia mulai menyerang Prakoso dengan bukti dan kata-kata" majas yang melukiskan sesuatu dengan mempergunakan benda, binatang, atau tumbuhan sebagai simbol atau lambang. Terdapat pada makna bukan melati kalau tidak bertameng duri artinya kutipan ini membanding dengan dengan tumbuhan sebagai simbol bahwa tokoh yang bernama melati 
dibandingkan dengan bunga melati yang mempunyai duri untuk melindunginya.

(2) Selanjutnya kutipan yang melukiskan sesuatu dengan mempergunakan benda, binatang, atau tumbuhan sebagai simbol atau lambang terdapat pada kutipan "Ia menatap tajam ke arah mata Melati, ternyata mata itu lebih tajam dari belati" makna dari kutipan tersebut ialah Prakoso merasa kaget ketika Melati mengancam dengan tatapan marah fotofoto bugilnya akan beberkan di tempat kerja Prakoso.

\section{c) Majas Sarkasme}

(1) Pada kutipan cerpen "Mampus kau, lancang! Mata-mata! Belajar jadi CIA di rumah sendiri? Hhh!" majas sindiran yang paling kasar terlihat bahwa kutipan ini menggambarkan tokoh prakoso begitu sangat marah kepada melati istrinya akibat disudutkan tentang perselingkuhannya.

(2) Selanjutnya kutipan yang mengungkapkan ungkapan sindiran kasar terlihan pada kutipan cerpen "Nanti kau akan tahu, betapa lezatnya hamburger jahanam ini, Prakoso!" makna dari kutipan ini adalah ungkapan hayati kepada Prakoso yang memperlihatkan foto-foto bugil Prakoso yang tidak pantas.

d) Majas Pleonasme

(1) Pada kutipan cerpen "ia mengerdipkan matanya nakal, sekali lagi dengan harapan, istrinya sudi menggembok mulutnya" majas yang menggunakan kata-kata secara berlebihan dengan maksud menegaskan arti suatu kata makna dari kutipan ini adalah Prakoso merayu Melati dengan mengerdipkan matanya agar Melati diam dan tidak membahas lagi tuduhan dan kecurigaannya kepada Prakoso.

(2) Selanjutnya kutipan yang menggunakan kata-kata secara berlebihan dengan maksud menegaskan arti suatu kata terdapat pada kutipan ".....adalah profesor ahlinya dalam hal perselingkuhan? Mereka adalah rujukan, referensiku paling lengkap dalam seluruh perjalanan dan lika-liku" ketika Melati menyebutkan temanteman Prakoso yang berselingkuh dan ternyata mereka adalah panutan Prakoso dalam selingkuh segala teka-tekinya dan semua caranya Prakoso dapakan ilmu dari teman-temannya.

(3) Berikutnya kutipan cerpen "Tetapi jika moralmu tidak lurus, itu akan menjadi urusanku, urusan kita berdua" makna dari kutipan tersebut adalah ungkapan Melati kepada Prakoso jika sikap dan kelakuan Prakoso tidak baik maka itu akan menjadi tanggung jawab mereka berdua.

(4) Berikutnya kutipan "Meminjam mata setan Prakoso memandangi bola mata Melati" makna dari kutipan ini adalah Prakoso yang marah karna disudutkan tak bisa mengelak lagi dia memandang tajam Melati begitu marah.

(5) Berikutnya kutipan cerpen "Ia pun mendarat di hutan paling pekat, masuk ke dalam puri indah selingkuhannya" makna dari kutipan ini adalah Prakoso sampai di tempat selingkuhannya dimana tempat yang membuatnya terjerumus dalam kemaksiatan.

e) Majas Metafora

(1) Pada kutipan cerpen "Prakoso terkesiap. Persis maling yang tertangkap" majas yang mengungkapkan ungkapan secara langsung berupa perbandingan analogis makna dari kutipan ini adalah Prakoso yang kaget ketika Melati membebekarkan foto perselingkuhannya dia tak bisa berkutik dan menengelak lagi hingga di ibarakan seperti Maling tertangkap basah.

(2) Berikutnya kutipan yang mengungkapkan ungkapan secara langsung berupa perbandingan analogis terdapat pada kutipan "Musuh di depan mata atau di ujung dunia, hanya kata yang mampu memanah dengan tepat ke arah jantungnya" makna dari kutipan ini adalah ketika Prakoso terus menyangkal dengan bukti yang ada maka Melati 
terus menyudutkannya dengan semua ucapannya.

\section{f) Majas Hiperbola}

Pada kutipan cerpen "Dengan seringai harimau lapar, tanpa guntur tak ada halilintar, ia terkam Melati dengan kedua sayapnya, sayap Burung Nasar yang perkasa. Ia terkami tulang leher Melati dengan sepuluh cakarnya, cakar-cakar srigala" berupa pernyataan berlebihan dari kenyataannya dengan maksud memberikan kesan mendalam atau meminta perhatian makna dari kutipan ini adalah Prakoso marah amat marah atas kebenaran perselingkuhannya dia murka dan memukul Hayati istrinya sampai tewas.

g) Majas Asosiasi

Pada kutipan cerpen "Seperti kilat, ia melesat dengan gairah penuh padat" majas yang membandingkan dua hal yang pada hakikatnya berbeda, tetapi sengaja dianggap sama makna dari kutipan ini adalah Prakoso yang merasa bersalah atas apa yang telah ia perbuat kepada Melati dan dalam kejaran polisi dia ingin bersembunyi ke tempat perselingkuhannya begitu tergesa-gesa dan cepat sehingga diibarakan seperti kilat.

Cerpen "Mayat Yang Mengambang Di Danau" karya Seno Gumira Ajidarma

\section{1) Sinopsis Cerpen}

Cerita ini dimulai dari kehidupan seorang pemburu ikan bernama Barnabas yang sangat giat memburu ikan dengan cara menyelam dan menombaknya. Tentu saja hasilnya untuk menghidupi Barnabas dan anaknya yang bernama Klemen. Barnabas berburu ikan guna menyambung hidup namun setiap hari Minggu ia menyempatkan diri untuk beribadah. Umumnya karena hanya pagi dan saat langit cerahlah Barnabas pergi menyelam untuk mulai mencari ikan. Ia memang tak suka memasang bubu dan tak juga suka memasang jala seperti banyak orang lainnya karena memasang bubu bukanlah berburu dan memasang jala juga bukanlah berburu meskipun kebanyakan orang di negeri bersalib itu ingin menjadi pendeta karena menjadi pendeta adalah kehidupan terpuji, namun Barnabas lebih memilih menjadi pemburu ikan. Tak ingin anaknya bernasib sama dengannya, Barnabas menginginkan Klemen untuk menjadi pendeta dan menyuruhnya pergi ke kota untuk belajar keagamaan. Kisah ini berakhir ketika negeri makmurnya kian berubah, mulai bergantinya perahu Bolotu menjadi raungan perahu Johnson, banyak ikan-ikan asing yang mulai mendominasi danau sehingga ikan-ikan asli jumlahnya berkurang bahkan hilang, maraknya penembakan dan kerusuhan di berbagai tempat, dan di kampus tempat belajar agama banyak diobrak-abrik tentara. Entahlah! Mungkin karena negeri ini sedang ditindas oleh makhluk-makhluk tak bermoral. Klemen pernah membacakan pesan pada benda kecil yang sering digunakannya pula untuk bicara kepada para algojo yang tak bermoral tersebut. Setelah kejadian itu, Klemen secara misterius menghilang.

Saat Barnabas tengah berburu ikan, dari dasar laut terdapat sosok mayat yang perlahan naik menuju permukaan danau. Barnabas sungguh tak menyangka bahwa mayat tersebut adalah Klemen, anak semata wayangnya, keluarga satu-satunya yang ia miliki. Kondisi Klemen sangat mengenaskan, tangan dan kaki terikat, dan pengikatnya adalah robekan bendera bergaris biru putih, sedangkan mulutnya disumpal dengan kain merah yang tak lain tak bukan adalah bendera Organisasi Papua Merdeka. Hujan yang deras seakan meratapi kepergian anaknya. Ini adalah kisah tentang semangat juang menyala dalam kehidupan sosok lelaki bernama Barnabas dan putranya bernama Klemen.

2) Gaya Bahasa Cerpen "Mayat Yang Mengambang Di Danau"

\section{a) Majas Asosiasi}

(1) Pada kutipan cerpen "Makanya ia pun berenang seperti ikan, mengapung seperti kayu, menyelam seperti pemberat-dan sekali tangannya bergerak, memang harus melesatkan 
tombaknya lebih cepat dari bekerjanya naluri ikan" majas yang membandingan dua hal yang pada hakikatnya berbeda, tetapi sengaja dianggap sama. Terlihat dari makna yang membandingkan tokoh yang berenang seperti ikan artinya sudah lihai dan tak diragukan lagi. Makna kutipan mengapung seperti kayu membandikan tokoh yang begitu lihai berenang dan mengapung layaknya kayu, dan menyelam seperti pemberat membandingkan bahwa tokoh tersebut saat menyelam bagaikan pemberat.

(2) Selanjutnya kutipan yang membandingan dua hal yang pada hakikatnya berbeda, tetapi sengaja dianggap sama terdapat pada kutipan “....tangannya hanya akan bergerak menombak secepat kilat bagaikan tak menunggu perintah otak" makna dari kutipan ini adalah kemampuan bernabas saat menombak ikan tidak diragukan lagi begitu lihat dan tangkas diibaratkan seperi kitak yang tak menunggu perintah dari otak.

\section{b) Majas Ironi}

Pada kutipan cerpen "Ikan makan ikan, apakah manusia tidak memakan manusia? Barnabas tidak terlalu peduli apakah ia pernah menjawab pertanyaannya sendiri” majas yang menyatakan hal yang bertentangan dengan maksud menyindir. Terlihat dari makna manusia memakan manusia hal ini menyindir dari segi sikap dan perbuatan manusia yang saling iri, saling meracuni, saling memecah belah, saling menjatuhkan dan lain-lain demi kepuan atau ambisi.

\section{c) Majas Personifikasi}

Pada kutipan cerpen "Angin keras menyapu seluruh permukaan danau, sehingga air hujan yang turun dari langit tersibak bagaikan tirai raksasa yang melambai-lambai" majas yang membandingkan benda-benda tak bernyawa seolah-olah mempunyai sifat seperti manusia.

\section{d) Majas Hiperbola}

Pada kutipan cerpen "Barnabas mulai menyelam tepat ketika langit bersemu keungu-unguan, saat angin dingin menyapu permukaan danau sehingga air berdesis pelan, sangat amat pelan, nyaris seperti berbisik, menyampaikan segenap rahasia yang bagai tidak akan pernah terungkapkan" majas yang berupa pernyataan berlebihan dari kenyataannya dengan maksud memberikan kesan mendalam atau meminta perhatian makna dari kutipan ini adalah sebuah suasana memdung dimana begitu pass waktu untuk mencari ikan saat itu keadaan dau begitu tenang.

\section{e) Majas Pleonasme}

(1) Pada kutipan cerpen "karena langit mendung dan mega hitam bergumpalgumpal" majas yang menggunakan kata-kata secara berlebihan dengan maksud menegaskan arti suatu kata makna dari kutipan tersebuat adalah langit yang mendung dan berawan begitu pekat akan turunnya hujan.

(2) Selanjutnaya kutipan yang menggunakan kata-kata secara berlebihan dengan maksud menegaskan arti suatu kata terdapat pada kutipan "memburu ikan, tanpa ikan-ikan itu harus tahu betapa jiwanya sedang terancam" makna dari kutipan ini adalah karna kelihaian Barnabas dalam menyelam dengan bagitu pelan sehingga ikan-ikan didalam danau tersebut yang sedang diincar tidak mengetahuinya.

(3) Berikutnya kutipan "Ikan gabus artinya ikan khahabei, besarnya bisa sebesar betispersembahan bagi ibu-ibu yang baru melahirkan" makna dari kutipan tersebut adalah ikan gabus yang berada di danau tersebut besarnya bisa mencapai sebesar bestis dan biasanya ikan tersebut dikonsumsi untuk perenpuan paska melahirkan.

(4) Berikutnya kutipan cerpen "setidaknya dua puluh sampai tiga puluh ikan yang bernasib malang di tangannya sudah 
tergantung di salah satu tiang dermaga" makna dari kutipan ini adalah setiap harinya jika cuaca bagus hasil tangkapan ikan Barnabas bisa mencapai duapuluh samapi tigapuluh yang ditangkapnya.

(5) Berikutnya kutipan cerpen "setiap orang harus cukup bersabar menantikan makhluk yang akan menyerahkan jiwa hari ini demi kelanjutan hidup pembunuhnya" makna dari kutipan ini adalah pada saat Barnabas memburu ikan ia harus sabar dan telaten karna bagaimanapun juga bekerja sebagai pemburu ikan demi kelangsungan hidupnya.

(6) Berikutannya kutipan cerpen "kepalanya juga akan dilempar sebagai pertunjukan kebuasan dunia yang tampaknya justru meningkatkan selera makan" makna dari kutipan ini adalah setelah ikan ditangkap dan dijual ikan akan dijadikan hidangan di sebuah restoran lalu kepalanaya akan dibuang dilaut dan menjadi santapan untuk ikanikan dilaut.

\section{f) Majas Simbolik}

Pada kutipan cerpen "Barnabas terus berenang di dalam air nyaris seperti ikan" majas yang melukiskan sesuatu dengan mempergunakan binatang sebagai simbol atau lambang makna dari kutipan ini adalah kelihaian Barnabas dalam menyelam dan berenang diibaratkan seperti ikan.

\section{g) Majas Retorik}

Pada kutipan cerpen "Apalah artinya menahan lapar sejenak untuk hidup lebih lama?" majas yang berupa kalimat tanya namun tak memerlukan jawaban makna dari kutipan ini adalah profesi Barnabas harus lebih menahan sabar karna memburu ikan tidaklah mudah ia harus menahan lapar demi kelangsungan hidupnya.

\section{h) Majas Metafora}

Pada kutipan cerpen "Di antara deru angin yang menarik-narik daun pohon nyiur di semua pulau, terdengarlah jeritan panjang dari tengah danau" majas yang mengungkapkan ungkapan secara langsung berupa perbandingan analogis makna dari kutipan tersebut adalah pada saat suasana pagi dengan hujan dan angin Barnabas menemukan mayat anaknya Klamen di dasar danau yang sudah beberapa hari menghilang, dia begitu terkejut lalu menjerit dengan menyebutkan nama anaknya.

\section{Perbandingan Gaya Bahasa Angkatan 66 dan Angkatan 2000}

Berdasarkan hasil analisis penggunaan gaya bahasa pada 10 cerpen Angkatan 66 terdapat 57 gaya bahasa dan 10 cerpen Angkatan 2000 terdapat 65 gaya bahasa, diperoleh jumlah keseluruhan dari total 20 cerpen 122 gaya bahasa. Total 65 gaya bahasa dari Angkatan 66 antara lain terdiri dari, 5 gaya bahasa asosiasi, 8 gaya bahasa metafora, 1 gaya bahasa personifikasi, 1 gaya bahsa metonomia, 6 gaya bahasa hiperbola, 4 gaya bahasa alegori, 8 gaya bahasa pleonasme, 2 gaya bahasa retorik, 6 gaya bahasa simbolik, 1 gaya bahasa ironi, 2 gaya bahasa sarkasme, 3 gaya bahasa sinisme, 4 gaya bahasa paradoks, 1 gaya bahasa antiklimaks, 1 gaya bahasa repetisi, 1 gaya bahasa antitesis, 1 gaya bahasa sinekdok, 1 gaya bahasa klimaks, 1 gaya bahasa tautologi. Sedangkan untuk total 57 gaya bahasa Angkatan 2000 antara lain terdiri dari, 7 gaya bahasa asosiasi, 4 gaya bahasa metafora, 5 gaya bahasa personofikasi, 6 gaya bahasa hiperbola, 10 gaya bahasa pleonasme, 3 gaya bahasa retorik, 4 gaya bahasa simbolik, 1 gaya bahasa ironi, 4 gaya bahasa sarkasme, 4 gaya bahasa sinisme, 2 gaya bahasa paradoks.

\section{DAFTAR PUSTAKA}

Abidin, Yunus. 2012. Pembelajaran Berbasis Karakter. Bandung: Afrika Aditama.

Aminuddin. 2013. Pengantar Apresiasi Karya Sastra. Bandung: Sinar Baru Algesindo. 
Amri, Sofan. 2013. Pengembangan dan Model Pembelajaran dalam Kurikulum 2013. Jakarta: Prestasi Pustakaraya.

Damono, Sapardi Djoko. 2005. Pegangan Penelitian Sastra Bandingan. Jakarta: Pusat Bahasa Departemen.

Endarswara, Suwardi. 2011. Metodologi Pengertian Sastra Bandingan. Jakarta: Buku Pop.

Jassin, H.B. 2013. Angkatan 66. Bandung: Pustaka Jaya.

Keraf, Gorys. 2009. Diksi dan Gaya Bahasa. Jakarta: Gramedia Pustaka Utama.

Komarudin. 2000. Kamus Istilah Karya Tulis Ilmiah. Jakarta. Bumi Aksara.

Kosasih, E. 2014. Jeni-jenis Teks. Bnadung: Yrama Widya.
Kurniawan, Heru dan Sutardi. 2012. Penulisan Sastra Kreatif. Yogyakarta: Graha Ilmu.

Nurgiatoro, Burhan. 2010. Penilaian Pembelajaran Bahasa Berbasis Kopetensi. Jogyakarta: BPFEJogyakarta.

Ratna, Nyoman Khuta. 2014. Stilistika Kajian Puistika Bahasa, Sastra, dan Budaya. Jogyakarta: Pustaka Belajar.

Sagala, Syaiful. 2013. Konsep dan Makna Pembelajaran. Bandung: Alfabeta.

Sugiono, 2009. Metode Penelitian Kuatitatif, Kualitatif dan $R \& D$. Bandung: Alfabeta.

Sumardjo, Jakob. 2004. Seluk Beluk dan Menulis Cerita Pendek. Bandung: Pustaka Latifah. 